\title{
Deep Integration: Considering the Heterogeneity of Free Trade Agreements
}

\author{
Jaime Ahcar \\ Pontificia Universidad Javeriana, Cali, Colombia \\ Jean-Marc Siroën \\ Université Paris-Dauphine PSL IRD LEDa UMR [225] DIAL, Paris, France
}

\begin{abstract}
Regional Trade Agreements have emerged in an environment of stalled multilateral trade negotiations. Although the impact of Regional Trade Agreements on international trade has been well documented, scant attention has been paid to empirical studies exploring their heterogeneity from the point of view of deep integration. We set out to determine whether deeper Regional Trade Agreements promote trade more effectively than less ambitious ones. We generate credible deep integration indicators using two recently available datasets from the World Trade Organization and the World Trade Institute. We then test the effect of depth on trade using a gravity model. We treat additive indicators as factor variables and use multiple correspondence analysis to obtain distilled indicators of deep integration to offer new insights and confirm recent deep integration findings. We find that deeper Regional Trade Agreements increase trade more than shallow agreements do, irrespective of whether the provisions they contain are within or beyond the competence of the World Trade Organization.
\end{abstract}

JEL Classifications: F13, F14, F15, F53

Keywords: Deep Integration, Gravity Model, Regional Trade Agreements, Trade Liberalization, International Trade.

\footnotetext{
* Correspondig Author: Jaime Ahcar; Pontificia Universidad Javeriana Cali, Economic Department, Calle 18 No 118-250, 760031 Cali, Colombia, Tel: +57 23218200, E-mail: jahcar@javerianacali.edu.co. 


\section{Introduction}

Although we now know more about whether Regional Trade Agreements (RTAs) increase trade flows (Rose 2004, Baier and Bergstrand 2007, Martínez-Zarzoso et al. 2009), estimates of RTAs frequently overlook thorny issues such as the heterogeneity of Free Trade Agreements (FTAs) and the concept of deep integration. A survey on this subject is provided by Kohl (2014). One question that has raised renewed interest is whether all RTAs are comparable. This study seeks to examine the nature of bilateral trade agreements and their specific content and to shed light on the implications of deep integration for bilateral trade flows.

The main contribution of this study is that we find that there is a significantly positive impact of deeper RTAs in trade creation when we use Multiple Correspondence Analysis (MCA) set of indicators of depth, which is a correspondence analysis-related method and better suited to qualitative variable applications than Principal Components Analysis (PCA) (Booysen et al. 2008). This study builds on previous studies by Shahid (2011), Orefice and Rocha (2013), Dür et al. (2014), Kohl et al. (2016), and Boughanmi et al. (2016). A second contribution is that we provide a clearer visualization of the impact of deeper trade agreements on bilateral exports by treating additive indicators as factor variables with clustered ranges. Thus, we find that a $10 \%$ increase in the depth of integration raises bilateral trade flows by around $3.0 \%$.

Globally, stalled multilateral trade liberalization and rising protectionism seem to be shaping the world trade in the second half of this decade; the US withdrawal from the Trans-Pacific Partnership (TPP) deal and Brexit are notable examples of this trend. Much of the hope of avoiding a downward spiral in international trade and living standards hinges on the ability of nations, particularly developing countries, to complete new and deeper RTAs (World Bank 2017).

Although all trade agreements are inherently designed to liberalize and regulate international trade, they also have remarkable differences: they vary in terms of number of signatories, economic weights, the distance between them, and the level of development among partners. No less important, they also vary in their depth, i.e., the number and nature of provisions included in the agreement. In addition to the obvious provisions on tariffs and rules of origin, the agreements often go further into non-tariff barriers, subject to agreements administered by the World Trade Organization (WTO) (e.g., intellectual property rights and sanitary and phytosanitary rules) or beyond the 
competence of the WTO, such as competition or labor standards.

RTAs are designed to not only secure market access but also seek broader international trade regulation. This does not necessarily mean that they create more trade. In some cases, they may even reduce it. Enforcement of intellectual property rights, included in many RTAs, can also end up reducing non-patented trade, not necessarily offset by a rise in trade in patented goods. As an outstanding example, The agreement between the European Union (EU), Colombia, and Peru (Official Journal of the European Union 354 2012) includes a provision for disarmament and non-proliferation of weapons of mass destruction, meaning less trade in some minerals and industrial goods such as nuclear reactors.

The current literature has not sufficiently explored the heterogeneity of RTAs. A better understanding of this topic would help raise awareness of its importance, evaluate its implications, and redefine the interpretation of the estimated RTA effect on trade and the limitations of trade liberalization. The common practice of using a dummy variable to introduce the effect of an RTA in a gravity model is tantamount to assuming that any pair of countries is treated the same, irrespective of the scope of the trade agreement. Finding a way to measure this heterogeneity and to associate it with the extent of depth of the agreements themselves generates indicators that can clarify the impact of this heterogeneity on bilateral trade flows. Following this introduction, Section II reviews the most important contributions made by the literature. Section III presents our dataset resources and our econometric model. Section IV reports the results. Section V presents a series of robustness checks and Section VI, concludes.

\section{Literature Review}

We use the WTO (2014) definition of RTAs as "reciprocal trade agreements between two or more partners," which is also the one largely shared by academics and international trade researchers. These agreements include free trade agreements and customs unions, together with more advanced schemes such as the EU single market. Preferential Trade Arrangements (PTAs), however, are non-reciprocal trade agreements. They include Generalized System of Preferences (GSP) schemes and other schemes granted a waiver by the WTO General Council. This study focuses essentially on RTAs, 
although the term regional is no longer relevant to these agreements as they frequently involve countries distant from each other.

Magee (2008) presented a classification of Preferential Agreements (PAs), Free Trade Agreements (FTAs), Customs Unions (CUs), and Common Markets (CMs) to estimate the impact of the depth of the agreements. Using a similar classification, Vicard (2009) found that "Once self-selection into agreements is controlled for, their trade creation effect does not statistically differ according to the depth of the RTA: creating an FTA, a $C U$, or a CM has a similar impact on trade among members." However, Magee (2008) and Vicard (2011) introduced terms of interaction between RTAs and some country characteristics to identify which trade agreements are more effective than others. Those signed by large and similar neighboring countries tend to perform better in terms of trade creation than smaller, more remote and dissimilar countries. The authors estimate different RTA effects for CUs, FTAs, and PAs in what is considered a measure of their depth. Although Baier, Bergstrand, and Feng (2014) did not use the same trade integration categories as previous studies, they provided evidence of the differential partial effect of different levels of Economic Integration Agreement (EIAs) on intensive and extensive trade margins.

These approaches do not focus so much on the reach, design, or content of the agreements as on the countries' intrinsic, observable characteristics. Recent generations of RTAs, which include not only provisions directly linked to market access for goods (including tariffs and non-tariff barriers) and services but also intellectual property rights, Singapore issues (investment, public procurement, trade facilitation, and competition), labor standards, environmental issues, and food standards, require a new approach to properly account for this complexity. (Kohr 2008).

Hoekman and Konan (2001) quantified the implications of a deeper RTA with general equilibrium model simulations for the EU-Egypt RTA. They found a welfare-increasing effect for potentially deeper agreements. This effect can neither be generalized nor taken for granted, since developing countries may be forsaking valuable industrial policy tools in exchange for greater market access and thus hampering their upward mobility in the international configuration of market specialization (Harrison and Rodríguez-Clare 2010, Shadlen 2005, and Rodrik et al. 2004).

An interesting approach used to assess the impact of deep integration is to compute the average tariff equivalents of non-tariff measures. Ghoneim et al. (2012) took TRAINS-UNCTAD data on non-tariff measures and found evidence of strong tradecreation potential on the basis of simulations of deeper integration between Southern 
Mediterranean countries and the EU. In the same vein, Péridy and Ghoneim (2013) took five Middle Eastern and North African countries and identified very high average tariff equivalents for their non-tariff measures that significantly reduce trade with their partners. However, this approach is problematic in terms of the small number of countries as well as the time period covered by the available databases.

Bourgeois, Dawar, and Evenett (2007) conducted a qualitative legal analysis of the content of 27 RTAs. They compared and described the discrepancies between these agreements by analyzing five provisions (labor market, competition policy, public procurement, environmental laws, and non-tariff barriers). Márquez-Ramos et al. (2011) found that democratic, free market-oriented economies are more likely to enhance an RTA. Another qualitative study of the external PTAs of the Association of South-East Asian Nation (ASEAN) is provided by Kleimann (2014), who concluded that bilateral PTAs between ASEAN members and the same external partners result in deeper commitments.

Many of the current developments in the field of deep integration come from the work of Horn et al. (2010), who codified EU and US RTA provisions and introduced non-traditional WTO provisions into the analysis. They also explore legal enforcement effects by identifying language nuances in RTA texts. This study avoids such a subjective judgment, even at the cost of assuming that all RTA provisions are equally enforceable.

Shahid (2011), Orefice and Rocha (2013), and Kohl et al. (2016) took the agreement content and empirical analysis a step further, based on WTO Research Division data for the World Trade Report (2011). Shahid (2011) concluded that the nature of RTAs matters, although the magnitude and direction of the relation remain unclear as deeper agreements can be exposed to diminishing returns. The results from Orefice and Rocha (2013), who use PCA and additive indicators, show that on average, deeper agreements increase trade in production networks between member countries by almost $12 \%$. Kohl (2014) found a positive correlation between the number of institutional quality provisions contained in RTAs and their average treatment effect. Kohl et al. (2016) found mixed results that show RTA heterogeneity can positively or negatively affect bilateral trade depending on the scope of the provisions. Traditional WTO provisions are found to have a positive effect, whereas non-traditional clauses have the opposite effect. Lastly, Dür et al. (2014) constructed their own enlarged database of 587 FTAs, 356 of which are listed by the WTO. The authors also conducted a latent trade analysis to compute a distilled indicator for the depth of the agreements. They found a significant positive relation between deeper agreements and bilateral trade flows. 
An alternative approach for dealing with the effects of the depth of the agreements was used by Boughanmi et al. (2016). They analyzed different integration scenarios using an 8.1 version of the Global Trade Analysis Project. The authors found that the lifting of RTA tariffs together with trade facilitation measures, which implies deeper integration, greatly improves the viability of the Gulf Cooperation Council countries' RTAs among Greater Arab Free Trade Area subgroups and with the EU. One of the most interesting features of such an analysis is that it allows for the possibility of exploring results for different scenarios of integration.

\section{Data and Methodology}

One of the main hurdles that deep integration literature faces is the lack of publicly available datasets documenting the content of a reasonably large sample of RTAs. This problem has recently been solved in part by two independent projects to codify RTAs by their different provisions: the WTO (2011) Research Division for the World Trade Report and the Design of Trade Agreements of the World Trade Institute (2014). We use these two datasets because they include RTA provisions, which are invaluable for producing credible deep integration indices.

\section{A. Deep integration indicators}

Taking the Horn et al. (2010) approach, we divided the first dataset into two main categories: WTO+ and WTO-X. The first category (Table 1) covers provisions within the competence of the WTO agreements and the second (Table 2) covers provisions beyond the WTO's current competence, but negotiated in RTAs worldwide. Some of the areas initially proposed by Horn et al. (2010) are not included here owing to a lack of variability or relevance 
Table 1. WTO+ policy areas negotiated in Regional Trade Agreements

Anti-Dumping

Countervailing Measures

GATS (General Agreement on Trade in Services)

Public Procurement

Sanitary and Phytosanitary Measures

State Aid (Subventions)

State Trading Enterprises

Technical Barriers to Trade

Trade Related Aspects of Intellectual Property Rights

TRIMS (Trade-Related Investment Measures)

(Source) Authors, based on Horn et al. (2010) classification.

It is worth noting that TRIPs and IPRs are closely related, as are TRIMs and investment measures, as they are negotiated both within and outside the scope of the WTO. When these provisions are present in RTAs, codified under the category WTO-X, we have to assume that these agreements go further than those usually provided for by the WTO.

Another problem arises with the WTO-X agricultural provision as many of the Table 1 provisions also apply to agricultural issues. We address this problem by computing indicators with and without these provisions. When a restricted dimension that excludes agriculture, IPRs, and investment appears in the analysis, we place an $r$ after the variable's name. 
Table 2. WTO-X provisions negotiated in RTAs

\begin{tabular}{|l|l|l|}
\hline Agriculture & wHealth & Nuclear safety \\
\hline Anti-corruption & Human rights & Political dialog \\
\hline Approximation of legislation & Illegal immigration & Public administration \\
\hline Audio-visual & Illicit drugs & Regional cooperation \\
\hline Competition policy & Industrial cooperation & Research and technology \\
\hline Consumer protection & Information society & Small-and-medium enterprises \\
\hline Cultural cooperation & Innovation policies & Social matters \\
\hline Data protection & Investment measures & Statistics \\
\hline Economic policy dialog & $\begin{array}{l}\text { Intellectual Property Rights } \\
\text { (IPRs) }\end{array}$ & Taxation \\
\hline Education and training & Labor market regulation & Terrorism \\
\hline Energy & Mining & Visa and asylum \\
\hline Environmental laws & Money laundering & \\
\hline Financial assistance & Movement of capital & \\
\hline
\end{tabular}

(Source) Authors, based on the Horn et al. (2010) classification

Figure 1 shows the growth in IPR, TRIM, and GATS provisions in new RTAs. Figure 2 presents the growth in environmental and labor market provisions based on our classification of the provisions in our sample of 103 RTAs. Provisions covering investment and services within the traditional scope of the WTO+ show an increasing trend over time. A similar trend is found for intellectual property rights measures, albeit with a loss of momentum in the 2008 2012 period compared with the 2002 2007 period (see Figure 1). This trend goes hand-in-hand with an increase in the number of RTAs over time. The percentage weight of these provisions has also risen over the past two decades. 
Figure 1. Number of new RTAs including IPR, investment or Service provisions

(1980 2012)

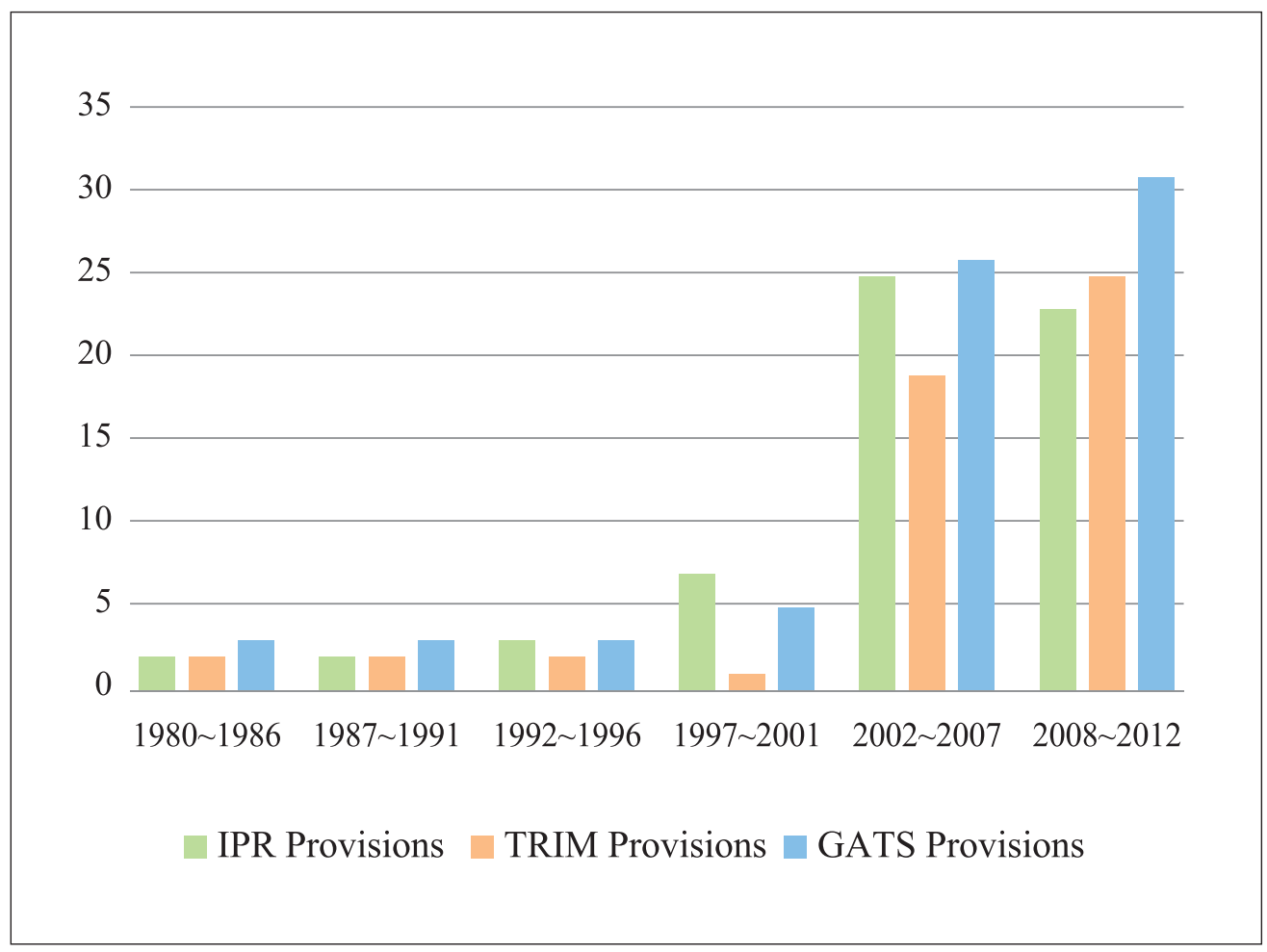

(Note) The number of IPR, TRIM and GATS provisions increases over time.

(Source) Elaborated by the authors from WTO (2011) research division for the World Trade Report.

Figure 2 clearly shows the surge in environmental and labor market regulation provisions, two of the most common WTO-X provisions negotiated in modern RTAs. In percentage terms, labor market regulation provisions have posted a sharper rise than environmental clauses have over the past two decades. Orefice and Rocha (2013) took the WTO (2011) dataset to conduct an empirical analysis of 66 RTAs and 200 countries from 1980 to 2007. The same dataset was also used by Shahid (2011) to analyze 97 RTAs and 132 countries over the 1994 2010 period. We build on the WTO (2011), covering 103 RTAs and 153 countries, in our calculations from 1980 to 2012. 
Figure 2. Number of new RTAs including environmental or labor market provisions

(1980 2012)

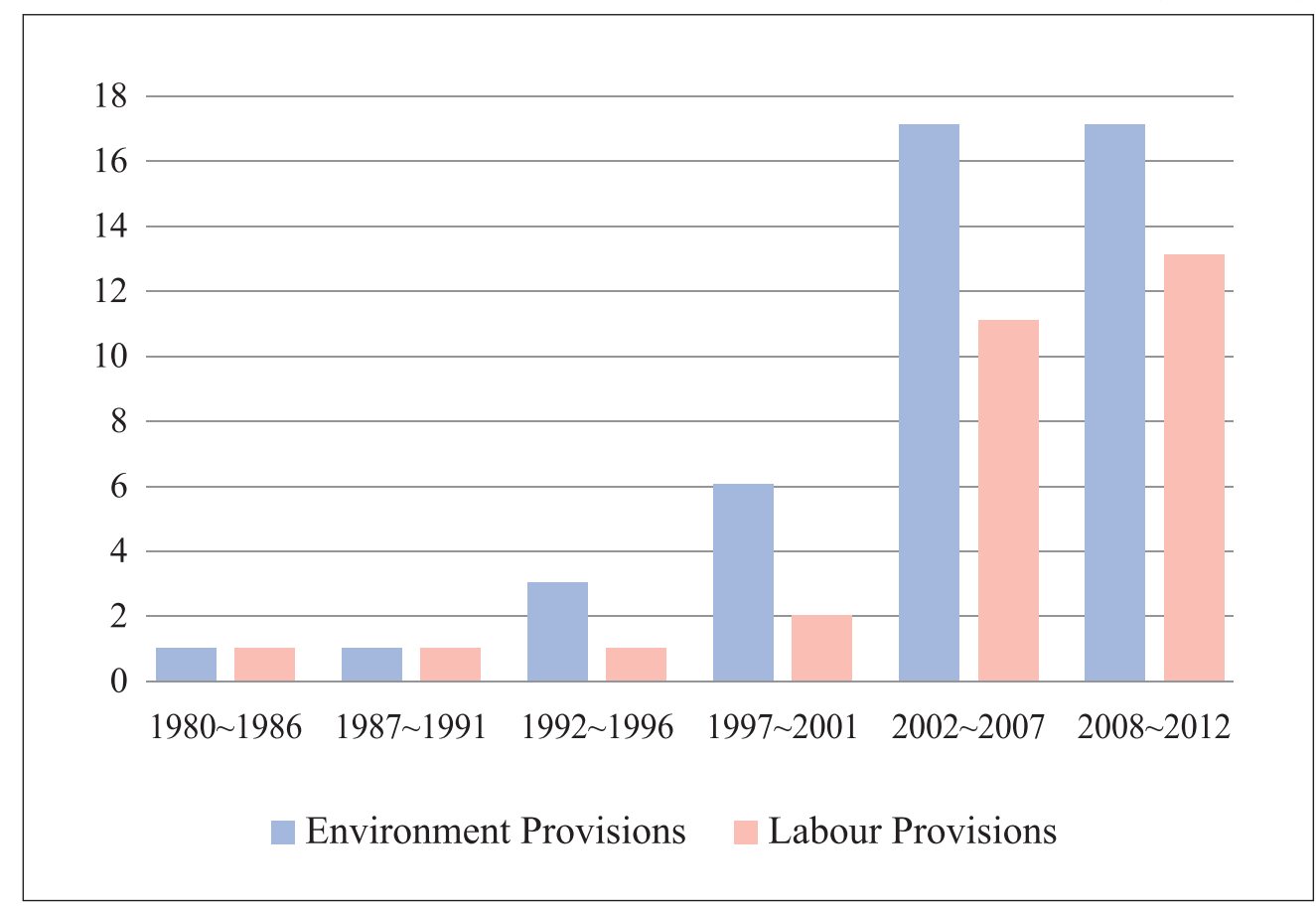

(Note) The number of IPR, TRIM and GATS provisions increases over time.

(Source) Elaborated by the authors from WTO (2011) research division for the World Trade Report.

Differences in country samples and periods of analysis explain the differences between RTAs considered in this study and those in previous studies. We code and include new agreements for Colombia and Peru, ${ }^{1}$ which were not available in the original WTO (2011) database, to offset the loss in RTAs subscribed to by countries such as the Faroe Islands, Montenegro, and San Marino.

The first step in building additive indicators of depth is to establish a set of provisions likely to appear in an RTA. The second step consists of counting how many of these provisions are found in a particular agreement. The advantage of this approach is that it is easy to compute. The disadvantage is that it assigns an equal weight to all the provisions embodied in an agreement. One RTA may have the same number of

\footnotetext{
${ }^{1}$ We have coded the following RTAs based on Horn et al. (2010): Canada-Colombia, Canada-Peru, Central America-Colombia, Chile-Colombia, Chile-Peru, Colombia-Cuba, Colombia-EFTA, Colombia-Mercosur, Colombia-USA, EFTA-Peru, Group of 3, JapanPeru, Peru-Mercosur, Peru-Republic of Korea, and Peru-USA
} 
provisions as another RTA but may differ entirely in terms of the subjects covered and the kinds of goods liberalized. Additive indicators can also be obtained by assigning different weights. However, in many cases this is done arbitrarily.

The number of provisions that an agreement incorporates does not in itself ensure the agreement's enforceability. However, we do not consider legal enforceability owing to the subjective nature of its codification process. Neither does an additive indicator guarantee that what we consider to be a very deep agreement, given its institutional maturity, will actually as such in the data. It is widely believed that Europe's single market is probably the deepest integration agreement. The EU members have eliminated all tariff barriers, harmonized product and service standards, and ensured political economic coordination. Nevertheless, counting non-weighted provisions may not necessarily be as accurate to define the depth of an RTA as we would wish. Thus, an additive indicator may give the EU's 1992 single market agreement a 5 while Colombia-USA is assigned a7 as in Dür et al. (2014). This situation arises because of the need to meet methodology requirements to prevent bias in the researcher's vision.

Some statistical methods have been developed to produce indicators that capture the inertia of a set of variables (characteristics) in a single dimension to deal with some of the additive indicators' drawbacks such as treating all the characteristics as equal. Orefice and Rocha (2013) use a PCA indicator. Dür et al. (2014) computed a Rasch indicator, which has the advantage of assuming that only one dimension is defined by the dataset's observations. Because binomial variables, of the kind we address in our analysis, are a particular type of categorical variable, a Multiple Correspondence Analysis (MCA) method is considered more suitable than PCA, which is best used for continuous variables (Cahuzac and Bontemps 2008, Dunteman 1989). MCA is then used to detect and represent underlying structures in a dataset and arrange data as points in a set of dimensions (Le Roux and Rouanet 2010).

The MCA of the traditional WTO-Competence provisions (WTO+) shows that more than $85 \%$ of the inertia is explained by the first dimension. We equate this dimension with a measure of deep integration. As an MCA method does not define the direction of the relation, we review its coherence such that the shallowest agreements in the MCA indicator take the lowest values. Hence, a higher index value stands for greater depth of integration. Likewise, we run an MCA for our restricted WTO-Xr provisions (excluding agriculture, intellectual property rights, and investment) to explore the impact of deeper agreements on provisions that are not traditionally within the WTO's competence. Here, some $89 \%$ of the inertia is explained by the first dimension. 


\section{B. Econometric specifications}

In his international trade gravity theory, Tinbergen (1962) claimed that bilateral international trade flows from country $i$ to country $j$, for a given year $t, X_{i j t}$, depend positively on the size of both economies $\mathrm{y}_{i t}$ and $\mathrm{y}_{j t}$, respectively, and negatively on a set of trade cost variables $t_{i j t}$. Anderson and Van Wincoop (2003) took up a micro-funded mathematical approach to better estimate the gravity equation (see Equation (1)), where $Y^{W}$ is world nominal income; $\theta_{i}$ and $\theta_{i}$ are shares of world income for country $i$ and country $j, \sigma$ is the elasticity of substitution between all goods, and $p_{i}$ and $\Pi_{i}$ are the price levels, respectively, in countries $i$ and $j$.

$$
X_{i j}=\frac{y_{i} y_{j}}{y^{w}}\left(\frac{t_{i j t}}{p_{i} \Pi_{j}}\right)^{l-\sigma}
$$

Anderson and Van Wincoop (2003) considered "multilateral resistance," or, the trade openness of countries $i$ and $j$ to the world. However, these variables are non-observable. A widely accepted solution is to introduce time-invariant fixed effects for importers and exporters, to avoid endogeneity from unobservable heterogeneity, as well as to partially control for omitted variable bias arising from multilateral resistance (Anderson 2011). ${ }^{2}$

To estimate the impact of the depth of RTAs, we regress bilateral export flows on a set of indicators of depth and covariates using a Poisson specification. Our gravity model dataset consists of 613,030 bilateral trade flows for 153 countries from 1980 to 2012 . Santos Silva and Tenreyro $(2006,2011)$ posit the Poisson Pseudo Maximum Likelihood (PPML) method as best suited to estimate the gravity equation. This method is robust to heteroscedasticity and deals with bias caused by the presence of many zeros in bilateral international trade data, which are positively related to distance and negatively related to market size. Baldwin and Harrigan (2011), Fally (2015), Martínez-Zarzoso (2013), and Head and Mayer (2014) provided additional evidence in support of the PPML estimator.

Appendix 3 presents information on the WTO+, WTO-X, and DESTA datasets. It shows the number of RTAs by their number of provisions and clustered number of provisions as well as by the number of bilateral trade flows affected by these RTAs. The DESTA dataset contains the largest number of RTAs, at 269, as opposed to 103 for WTO

\footnotetext{
${ }^{2}$ Time-Varying Fixed Effects (TVFE) can be introduced into the gravity equation to better account for multilateral resistance. Nevertheless, we do not control for country TVFE in the body of this study because of computational complexities associated with the PPML method which calls for the computation of too many fixed effects. For robustness, we check the effects of TVFE with OLS. Using the Baier \& Bergstrand method, which contracts the time dimension, we also check the effects of TVFE with PPML for the factor variable indicators.
} 
and WTO-X. Our depth indicators are tested in terms of level, as factor variables, and in logarithms. We use the four following specifications:

Our first Equation (2) specification allows us to express our depth indicators in levels: additive, MCA, or Rasch. We use subscript ${ }_{\mathrm{m}}$ to indicate the kind of indicator we are estimating (level, logarithmic, or MCA):

$$
X_{i j t}=\exp \left(\beta_{0}+\beta_{l} \boldsymbol{d} \boldsymbol{p}_{\text {indijtm }}+\vartheta_{l} \boldsymbol{G}_{i j t}+\psi_{h} \boldsymbol{S}_{i t}+\phi_{h} \boldsymbol{M}_{j t}+\alpha_{t}+\alpha_{i}+\alpha_{j}\right) u_{i j t}
$$

where the dependent variable $X_{i j t}$ represents bilateral FOB exports in current dollars from country $i$ to country $j$ and $u_{i j t}=\exp \left((1-\sigma) \varepsilon_{i j t}\right) . S_{i t}$ and $\boldsymbol{M}_{j t}$ are vectors of time varying idiosyncratic controls for exporters and importers, respectively, composed of $h$ control variables. Control variables are $\ln \left(G D P_{i t}\right)$ and $\ln \left(G D P_{j t}\right)$, the natural logarithm for GDP in current dollars; $\ln \left(\right.$ pop $\left._{i t}\right)$ and $\ln \left(\mathrm{pop}_{j t}\right)$, the natural logarithm for population; $G A T T_{i t}, G A T T_{j t}, O E C D_{i t}$, and OECD $D_{j t}$ take the value 1 if the country belongs to the GATT/WTO and Organization for Economic Cooperation and Development (OECD), respectively, on date $t$.

$\mathrm{G}_{i j t}$ is a vector of bilateral variables consisting of $\operatorname{contg}_{i j}$, as a dummy for sharing a common land border; comlang $_{i j}$, is a dummy for sharing the same language; col45 $_{i j t,}$ is a dummy for colonized countries before 1945; and lndist $_{i j t}$ is the natural logarithm for distance between countries $i$ and $j$. Correspondingly, $\vartheta_{l}$ is a vector of coefficients to be estimated for these variables where subscript ${ }_{l}$ is used to indicate the variables.

We also have the year fixed effect $\alpha_{t}$, time-invariant fixed effects $\alpha_{i}$ and $\alpha_{j}$ for exporters and importers, and error term, $u_{i j t}$. Sources and definitions are available in Appendix 1. As we account for time-invariant country fixed effects, the inclusion of traditional variables such as the country's surface area or its insular or landlocked status is redundant.

We introduce our indicator in logarithmic form so that the reasoning can be in terms of percentage variations. We then choose to add 1 to the index before using a logarithm to deal with zeros, as seen in Equation (3):

$$
X_{i j t}=\exp \left(\beta_{0}+\beta_{l} \boldsymbol{l n}\left[\mathbf{1}+\boldsymbol{d} \boldsymbol{p}_{\text {Ind }_{i j t m}}\right]+\vartheta_{l} G_{i j t}+\psi_{h} S_{i t}+\phi_{h} \boldsymbol{M}_{j t}+\alpha_{t}+\alpha_{i}+\alpha_{j}\right) u_{i j t}
$$

Next, the econometric specification of Equation (4) introduces our additive depth indicators for WTO+, WTO-X, and DESTA as factor variables. To address this point, we create a dummy variable for each range of RTAs based on the number of provisions 
they have. As some ranges of provisions are associated with a limited number of RTAs, particularly with respect to WTO-X, we test this specification by regrouping the RTAs into fewer ranges, where $\delta_{i j t}$ represents the coefficients for each of these ranges.

$$
X_{i j t}=\exp \left(\beta_{0}++\vartheta_{l} \boldsymbol{G}_{i j t}+\psi_{h} \boldsymbol{S}_{\boldsymbol{i t}}+\phi_{h} \boldsymbol{M}_{\boldsymbol{j} t}+\delta_{i j t n-1} \sum_{1}^{n-1} \boldsymbol{d} \boldsymbol{p}_{\text {ind }_{\text {add }} \text { nijt }}+\alpha_{t}+\alpha_{i}+\alpha_{j}\right) u_{i j t}
$$

We use Equation (5) to identify possible nonlinearities, such as diminishing or increasing returns, and test our additive indicators in a quadratic form.

$$
X_{i j t}=\exp \left(\beta_{0}+\beta_{l} \boldsymbol{d} \boldsymbol{p}_{\text {Ind }_{i j t}}+\beta_{2} d \boldsymbol{p}_{\text {Ind }}^{2} \underset{i j t}{2}+\vartheta_{l} \boldsymbol{G}_{i j t}+\psi_{h} \boldsymbol{S}_{i t}+\phi_{h} \boldsymbol{M}_{\boldsymbol{j} t}+\alpha_{t}+\alpha_{i}+\alpha_{j}\right) u_{i j t}
$$

\section{Results}

We first discuss our findings for the additive indicators before moving on to the factor variable specification. We then present our estimates of distilled depth indicators using the MCA and Rasch models.

\section{A. Deep integration additive indicators}

Our variables of interest here are $\left(a d_{-} W T O+\right)$ and $\left(a d \_W T O \_X\right)$, which consist of the additive index of provisions within and outside the regular WTO frameworks, respectively. We also test the variable ( $\left.a d \_D E S\right)$, which is the additive index based on the DESTA database.

These variables take the value 0 when there is no RTA, value 1 when a signed trade agreement has no provisions, value 2 when the agreement has one provision and so forth, up to the index of deepest RTAs, which is 11 for $a d \_W T O+, 32$ for ad_WTO_X, and eight for $a d \_D E S$. Thus, $a d^{2}{ }_{-} W T O+, a d^{2} \_W T O \_X$, and $a d^{2} \_D E S$ are their quadratic forms. Likewise, $I n \_a d \_W T O, \ln \_a d \_W T O \_X$, and $\ln \_a d \_D E S$ are their logarithmic 
expressions. Variables expressed in levels take the Equation (2) specification and the log variables, do that of the Equation (3) specification.

A positive significant effect is found for every specification in Table 3. A 10\% increase in the number of traditional WTO+ provisions increases bilateral trade by approximately $2.5 \%$, just as it does for the DESTA classification of provisions. A slightly smaller effect can be attributed to an increase in non-traditional WTO-X provisions. When tested in their quadratic specification, additive indicators reveal decreasing returns to the process of integration.

The results displayed in Table 4 come from the transformation of our ad_WTO+, $a d \_W T O-X$, and DESTA additive indicators into factor variables, as in Equation (4). Ranking the number of RTAs available by number of provisions shows that most of the RTAs are in the shallowest ranges of provisions. See the Appendix 3 for details.

For WTO+ provisions, this process consists of generating 12 dummies including the no-agreement case $(a d+W T O+1)$, which is chosen as the excluded category; the RTA with no-provisions $\operatorname{case}^{3}\left(a d \_W T O+2\right)$, and $\left(a d \_W T O+3\right.$ to $\left.a d \_W T O+12\right)$ for the 10 different provisions within the WTO+ framework. To ensure sufficient RTA representation in each cluster of factor variables, we regroup the provisions into four ranges. Hence, the effect of deeper integration on bilateral exports increases with the number of provisions included in the RTAs. We use the same procedure to analyze the WTO-X additive indicator as a factor variable. Because of the large number of provisions, we generate dummy variables for four ranges. The results are presented in column 2 of Table 4. We do the same for the DESTA additive index, which is based on eight general provisions before they are clustered into four ranges.

Although all our results are positive for $W T O-X$ provisions, we do not find the same increasing pattern here as for $W T O+$. The column 3 in Table 4 shows that introducing the DESTA additive depth indicators into our gravity equation as factor variables in a four-range ranking produces a pattern that is consistent with those obtained from WTO+ provisions, when we test them as factor variables under a four-range ranking.

Treating the WTO+ and DESTA additive indicators as factor variables clustered into four successive ranges clearly shows that RTAs tend to have a greater impact on bilateral trade flows when they include an increasing number of provisions.

${ }^{3}$ For example: ASEAN, PAFTA, Russia-Ukraine, Ukraine-Kazakhstan, and Ukraine-Turkmenistan 


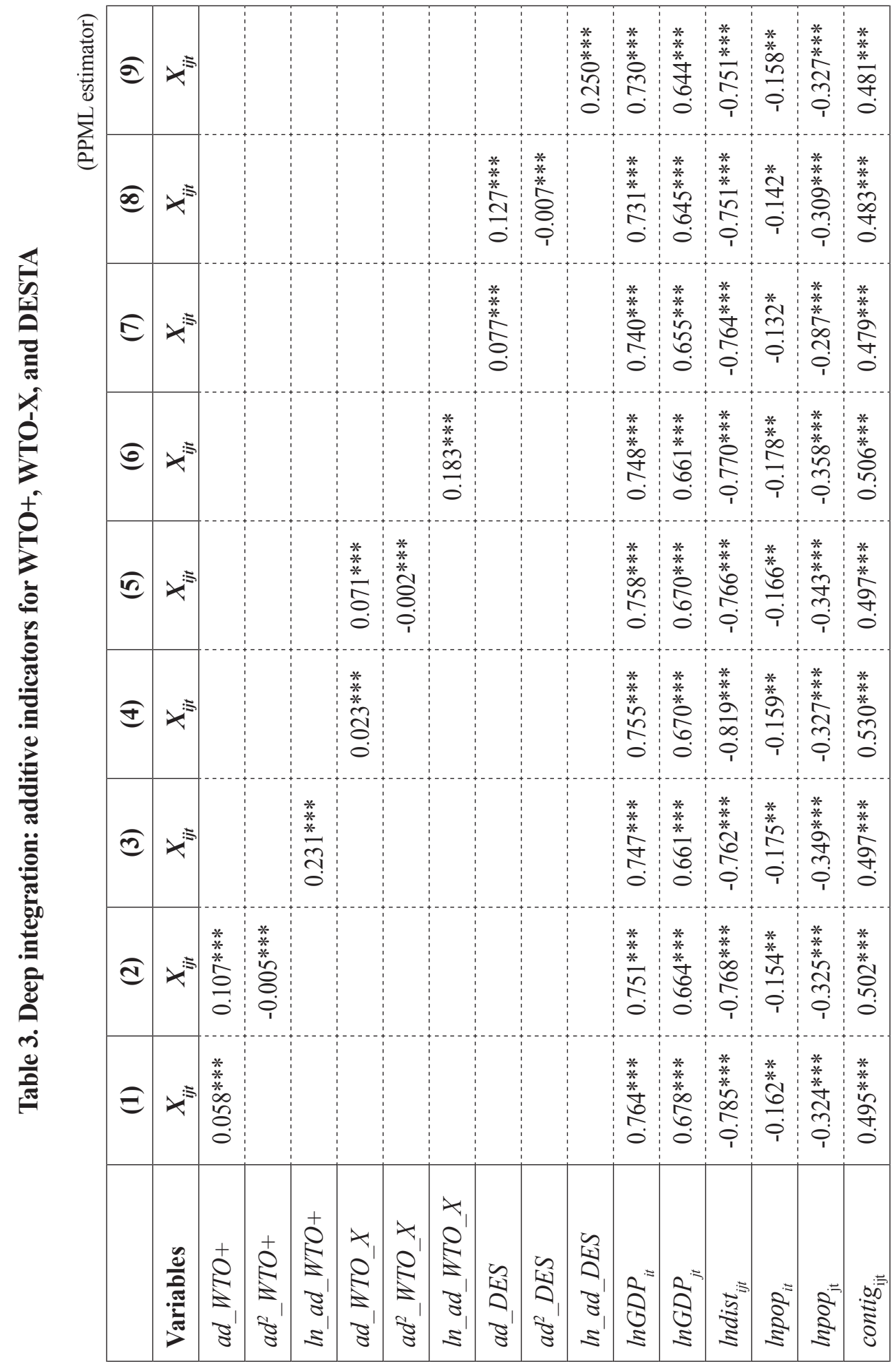




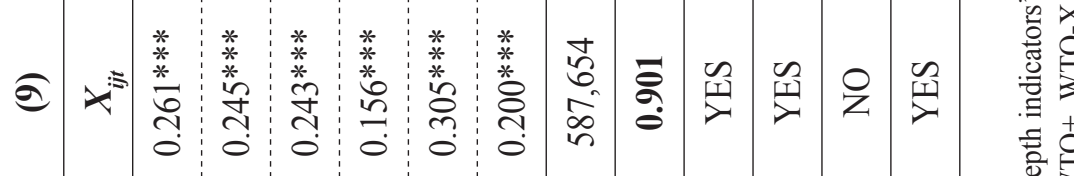

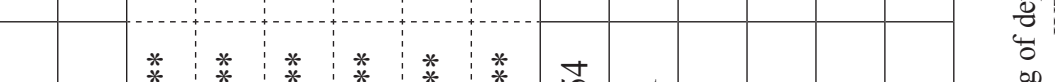

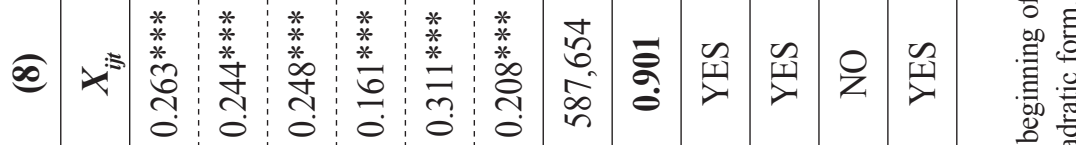

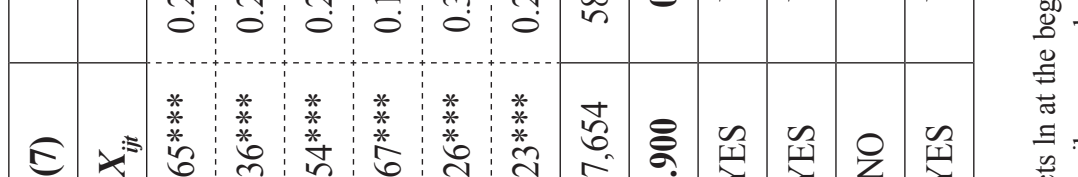

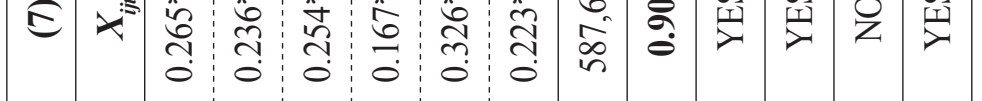

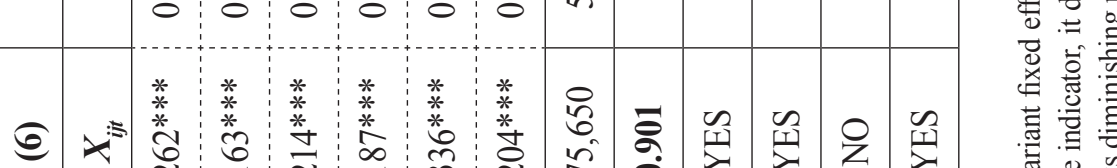

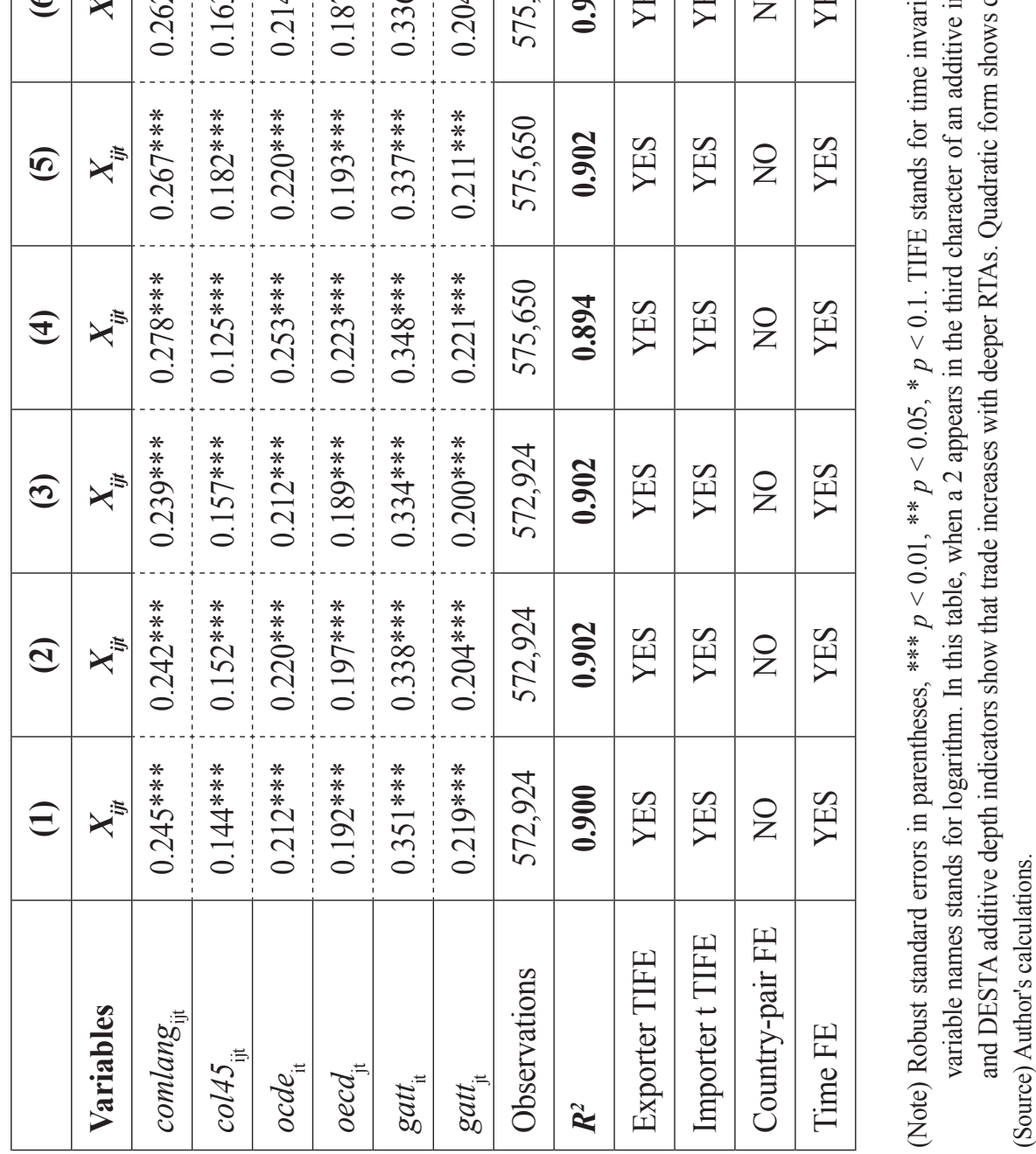


In Section V.A, where we present our robustness checks, we test whether our results are sensitive to the number of ranges selected. Henceforth, to make the tables lighter, our results focus on our variables of interest (depth indicators). Covariate estimates are available in Ahcar and Siroën (2014).

\section{Table 4. Deep integration: additive indicators as factor variables by WTO+, WTO-X, and DESTA provisions}

(Divided into four)

\begin{tabular}{|c|c|c|c|c|c|}
\hline & (1) & & (2) & & (3) \\
\hline & $X_{i j t}$ & & $X_{i j t}$ & & $X_{i j t}$ \\
\hline ad_WTO+2 & $0.249 * * *$ & $a d \_W T O \_X 2$ & $0.449^{* * *}$ & ad_DES2 & $0.267^{* * *}$ \\
\hline ad_WTO+3 & $0.486^{* * *}$ & ad_WTO_X3 & $0.533^{* * *}$ & ad_DES3 & $0.429^{* * *}$ \\
\hline ad_WTO+4 & $0.488^{* * *}$ & ad_WTO_X4 & $0.344^{* * *}$ & ad_DES4 & $0.532 * * *$ \\
\hline Observations & 572,924 & & 575,65 & & 587,654 \\
\hline$R^{2}$ & 0.902 & & 0.900 & & 0.900 \\
\hline Exporter TIFE & YES & & YES & & YES \\
\hline Importer TIFE & YES & & YES & & YES \\
\hline Country-pair FE & NO & & NO & & NO \\
\hline Time FE & YES & & YES & & YES \\
\hline
\end{tabular}

(Note) Additive indicators are divided into four ranges. Range 1 is the reference category where there is no RTA. Range 2 is the shallowest, and range 4 the deepest. WTO+ and DESTA depth indicators show that trade increases as the number of provisions increases. TIFE stands for time invariant fixed effects.

(Source) Author's calculations.

\section{B. Distilled deep integration indicators}

This section presents the results for a set of distilled deep integration variables, obtained from the first dimension of A Multiple Correspondence Analysis (MCA) ${ }^{4}$ process, and a set of variables generated by the Rasch methodology computed by Dür

\footnotetext{
${ }^{4}$ Regarding traditional WTO policy areas, the MCA indicator for the first dimension captures $85.6 \%$ of the inertia. It captures $88.8 \%$ of the inertia in the case of WTO-X provisions. We also compute an MCA for WTO-X excluding agriculture, investment, and IPR from the set of provisions presented in Table 2. The first dimension of this restrained MCA accounts for $89.7 \%$ of the inertia.
} 
et al. (2014) with DESTA inputs. We also explore the possibility of non-linearities in the process of trade integration by introducing quadratic terms for our MCA indicators for WTO and WTO-X provisions and Rasch indicators in Table 5. We develop two separate sets of indicators, based on WTO+ provisions and WTO-X provisions. We try out specifications in levels, logarithms,

and quadratics to test the sensitivity of these indicators.

We consider $m c a_{-} W T O+$ and $m c a_{-} W T O \_X$, which are $M C A$ indices obtained from their first dimension of inertia, to capture RTA depth based on the number and combination of traditional WTO+ and WTO-X provisions they embody; mca $^{2}$ WTO+ and $m c a^{2}{ }_{W T O} X$ are their squared forms and $l n \_m c a \_W T O+$ and $l n \_m c a \_W T O \_X$ are their natural logarithms. Rasch variable names use these same conventions.

Use of the character $r$ (as restrained) at the end of a variable ( $m c a \_W T O \_X r, m c a^{2}$ $W T O \_X r$ and $l n \_m c a \_W T O \_X r$ ) means that it excludes agriculture, investment, and IPR because these provisions are already covered, for all intents and purposes, by the traditional WTO+ framework. This restriction does not change the sign or the significance of these indicators but increases the value of the coefficients in all specifications (see Table 6). The Rasch index in Table 6 is positive and significant. When tested in their quadratic form, we find diminishing returns to the deepening of trade integration.

\section{Robustness}

In this section, we check the sensitivity of our results to the clustering of provisions, the introduction of time-variant country fixed effects, and the use of PCA.

\section{A. Related indicators}

Here, we analyze the sensitivity of the WTO+ clusters. column 2 in Table 6 reproduces the breakdown presented in Table 3 to make the analysis easier. A comparison of results in column 2 of Table 6 , which presents five ranges, and in column 3, which presents three ranges, finds that the $\mathrm{WTO}+$ results are robust to an increase from four to five 


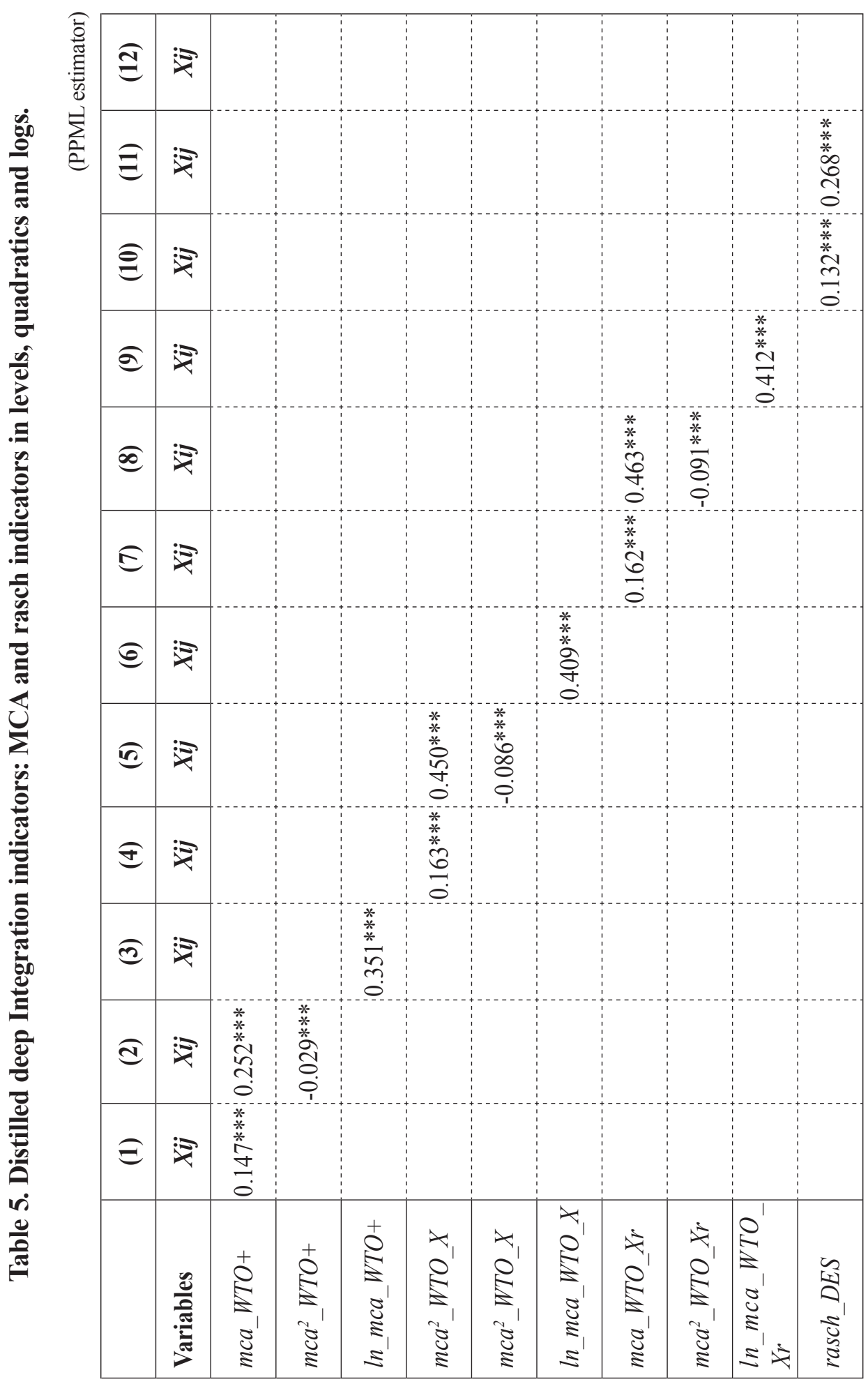


禀

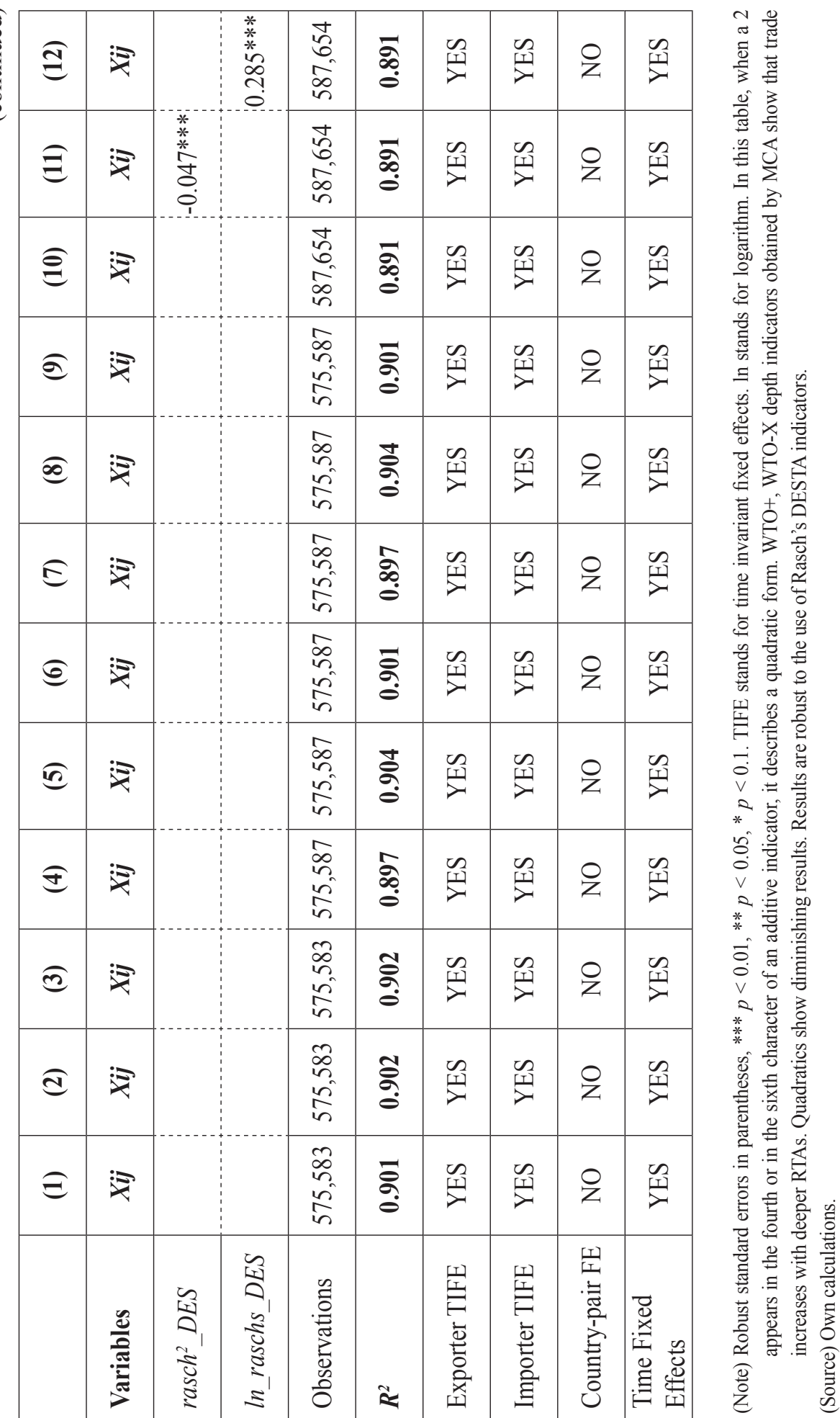


ranges as well as to a decrease from four to three ranges. This confirms the argument that introducing more $\mathrm{WTO}+$ provisions into the RTAs can be expected to have a larger impact on trade.

Table 6. Deep integration: additive indicator as a factor variable from WTO+

(Divided into 5, 4, and 3 ranges. PPML estimator)

\begin{tabular}{|c|c|c|c|c|c|}
\hline & (1) & & (2) & & (3) \\
\hline & Xijt & & Xijt & & Xijt \\
\hline \multirow[t]{2}{*}{$a d \_W T O+2 a$} & $0.231 * * *$ & $a d \_W T O+2$ & $0.249 * * *$ & $a d \_W T O+2 b$ & $0.345^{* * *}$ \\
\hline & $(0.028)$ & & $(0.028)$ & & $(0.021)$ \\
\hline \multirow{2}{*}{$a d \_W T O+3 a$} & $0.411 * * *$ & $a d \_W T O+3$ & $0.486 * * *$ & $a d \_W T O+3 b$ & $0.543 * * *$ \\
\hline & $(0.021)$ & & $(0.021)$ & & $(0.019)$ \\
\hline \multirow[t]{2}{*}{$a d \_W T O+4 a$} & $0.518 * * *$ & $a d \_W T O+4$ & $0.488 * * *$ & & \\
\hline & $(0.022)$ & & $(0.023)$ & & \\
\hline \multirow[t]{2}{*}{$a d \_W T O+5 a$} & $0.565^{* * *}$ & & & & \\
\hline & $(0.029)$ & & & & \\
\hline Observations & 572924 & & 572,924 & & 572,924 \\
\hline$R^{2}$ & 0,903 & & 0.902 & & 0.903 \\
\hline Exporter TIFE & YES & & YES & & YES \\
\hline Importer TIFE & YES & & YES & & YES \\
\hline Country-pair FE & NO & & NO & & $\mathrm{NO}$ \\
\hline Time FE & YES & & YES & & YES \\
\hline
\end{tabular}

(Note) Robust standard errors in parentheses, ${ }^{* * *} p<0.01,{ }^{* *} p<0.05, * p<0.1$. TIFE stands for time invariant fixed effects. Letters $a$ and $b$ at the end of a variable name means that the ranges are regrouped together in five and three ranges, respectively. Range 1 is the reference category where there is no RTA. Range 2 is the shallowest, and range 5, in the first column, range 4 in the second column, and range 3 in the third column are the deepest ranges. WTO+ depth indicators show that trade increases as the number of provisions increases. Results are robust to the regrouping of ranges.

(Source) Author's calculations.

Moving on to the sensitivity of the WTO-X provisions, Table 7, column 2 reproduces the results presented in Table 6. A reduction in the number of ranges clustering the provisions from four to three (column 3) produces a result where deeper agreements raise trade more than shallow ones. 
Nevertheless, this finding is not confirmed when we raise the number from four to five ranges (see column 1), whereas deeper agreements seem to increase trade more than shallow ones up to a certain point in column 2 where more integration appears to raise trade but to a lesser extent than before.

Table 7. Deep integration: additive indicator as a factor variable from WTO-X.

(Divided into 5, 4, and 3 ranges. PPML estimator)

\begin{tabular}{|c|c|c|c|c|c|}
\hline & (1) & & (2) & & (3) \\
\hline & Xijt & & Xijt & & Xijt \\
\hline \multirow[t]{2}{*}{$a d \_W T O \_X 2 a$} & $0.306^{* * *}$ & ad_WTO_X2 & $0.449 * * *$ & $a d \_W T O \_X 2 b$ & $0.407 * * *$ \\
\hline & $(0.024)$ & & $(0.019)$ & & $(0.020)$ \\
\hline \multirow{2}{*}{$a d \_W T O \_X 3 a$} & $0.456 * * *$ & ad_WTO_X3 & $0.533 * * *$ & $a d \_W T O \_X 3 b$ & $0.502 * * *$ \\
\hline & $(0.023)$ & & $(0.021)$ & & $(0.019)$ \\
\hline \multirow[t]{2}{*}{$a d_{-} W T O \_X 4 a$} & $0.551^{* * *}$ & ad_WTO_X4 & $0.344^{* * *}$ & & \\
\hline & $(0.022)$ & & $(0.028)$ & & \\
\hline \multirow[t]{2}{*}{$a d \_W T O \_X 5 a$} & $0.426 * * *$ & & & & \\
\hline & $(0.021)$ & & & & \\
\hline Observations & 575,650 & & 575.650 & & 575,650 \\
\hline$R^{2}$ & 0.903 & & 0,9 & & 0.903 \\
\hline Exporter TIFE & YES & & YES & & YES \\
\hline Importer TIFE & YES & & YES & & YES \\
\hline Country-pair FE & $\mathrm{NO}$ & & NO & & $\mathrm{NO}$ \\
\hline Time FE & YES & & YES & & YES \\
\hline
\end{tabular}

(Note) Robust standard errors in parentheses, ${ }^{* * *} p<0.01, * * p<0.05, * p<0.1$. TIFE stands for time invariant fixed effects. Letters $a$ and $b$ at the end of a variable name means that the ranges are regrouped together in 5 and 3 ranges respectively. Range 1 is the reference category where there is no RTA. Range 2 is the shallowest, and range 5 , in the first column, range 4 in the second column, and range 3 in the third column are the deepest ranges. WTO-X depth indicators regrouped in 3 categories, column 3, show that that trade increases as the number of provisions increases.

(Source) Author's calculations.

As above, column 2 of Table 8 presents the sensitivity results for the four-range breakdown displayed in column 3 of Table 3. We compare these results with the clusters including five and three ranges (column 1 and column 3). A five-range classification, 
as in column 1, suggests a positive, increasing impact on bilateral exports induced by the increase in the number of provisions in an RTA. Reducing the number of ranges to three, as in column 3, confirms the same pattern as column 1 and column 2 where RTAs with more provisions generate a greater increase in bilateral exports. Our results for the DESTA additive RTA classification are robust to changes in the factor variable specification clusters.

Table 8. Deep Integration : additive indicator as a factor variable from DESTA

(Divided into 5, 4, and 3 ranges. PPML estimator)

\begin{tabular}{|c|c|c|c|c|c|}
\hline & (1) & & (2) & & (3) \\
\hline & Xijt & & Xijt & & Xijt \\
\hline \multirow[t]{2}{*}{$a d 2_{2} D E S a$} & $0.189 * * *$ & $a d 2 \_D E S$ & $0.267 * * *$ & $a d 2 \_D E S b$ & $0.277 * * *$ \\
\hline & $(0.045)$ & & $(0.024)$ & & $(0.024)$ \\
\hline \multirow[t]{2}{*}{$a d 3 \_D E S a$} & $0.281 * * *$ & $a d 3 \_D E S$ & $0.429 * * *$ & $a d 3 \_D E S b$ & $0.465^{* * *}$ \\
\hline & $(0.025)$ & & $(0.019)$ & & $(0.018)$ \\
\hline \multirow[t]{2}{*}{$a d 4 \_D E S a$} & $0.398 * * *$ & $a d 4 \_D E S$ & $0.532 * * *$ & & \\
\hline & $(0.020)$ & & $(0.028)$ & & \\
\hline$a d 5 \_D E S a$ & $0.506^{* * *}$ & & & & \\
\hline Observations & 587.654 & & 587.654 & & 587,654 \\
\hline$R^{2}$ & 0,901 & & 0.900 & & 0.900 \\
\hline Exporter TIFE & YES & & YES & & YES \\
\hline Importer TIFE & YES & & YES & & YES \\
\hline Country-pair FE & NO & & $\mathrm{NO}$ & & $\mathrm{NO}$ \\
\hline Time FE & YES & & YES & & YES \\
\hline
\end{tabular}

(Note) Robust standard errors in parentheses, ${ }^{* * *} p<0.01, * * p<0.05, * p<0.1$. TIFE stands for time invariant fixed effects. Letters $\mathrm{a}$ and $\mathrm{b}$ at the end of a variable name means that the ranges are regrouped together in 5 and 3 categories respectively. Range 1 is the reference category where there is no RTA. Range 2 is the shallowest, and range 5, in the first column, range 4 in the second column, and range 3 in the third column are the deepest ranges. DESTA depth indicators show that trade increases as the number of provisions increase. Results are robust to the regrouping of ranges.

(Source) Author's calculations. 


\section{B. Other estimators}

We worked previously on time-invariant country fixed effects. The introduction of time-varying fixed effects into the analysis gives us elements to assess the robustness of the results hitherto presented as they reduce omitted variable bias. Estimation of the entire set of indicators using PPML and time-varying fixed effects for the full 33-year period is not feasible for the time being owing to PPML convergence difficulties when a large number of fixed effects have to be evaluated. In contrast, the OLS procedure for time-varying fixed effects is more practicable (Guimaraes and Portugal 2010). Our set of additive depth indicators is then re-estimated using OLS and with time-varying country fixed effects. Our previous results are robust (Table 9). WTO-X provisions display lower coefficients than WTO+ provisions. This remains valid irrespective of whether the specification is in level, quadratic, or logarithm form.

We also tested the specification including time-varying fixed effects together with country-pair fixed effects on four-year intervals in keeping with the Baier and Bergstrand (2007) technique. Estimates (available on demand) revise levels, quadratics, and logs downwards slightly in all three main specifications, as well as across the WTO domains and databases. Although the inclusion of country-pair fixed effects usually reduces the previous RTA-related estimates, our results remain robust to the Baier and Bergstrand technique and the inclusion of time-varying country fixed effects and country-pair fixed effects.

Table 10 presents a sensitivity analysis for our factor variable breakdown of WTO+, WTO_X, and DESTA additive indicators based on the introduction of timevarying country fixed effects. We compare the results with OLS and PPML. Column 1 is estimated with OLS and time-varying fixed effects. columns 2 uses Baier and Bergstrand's technique and puts country-pair fixed effects together in the same equation as time-varying fixed effects estimated by OLS over four-year intervals. column 3 uses PPML and time-varying fixed effects over four-year intervals but not country-pair fixed effects. 


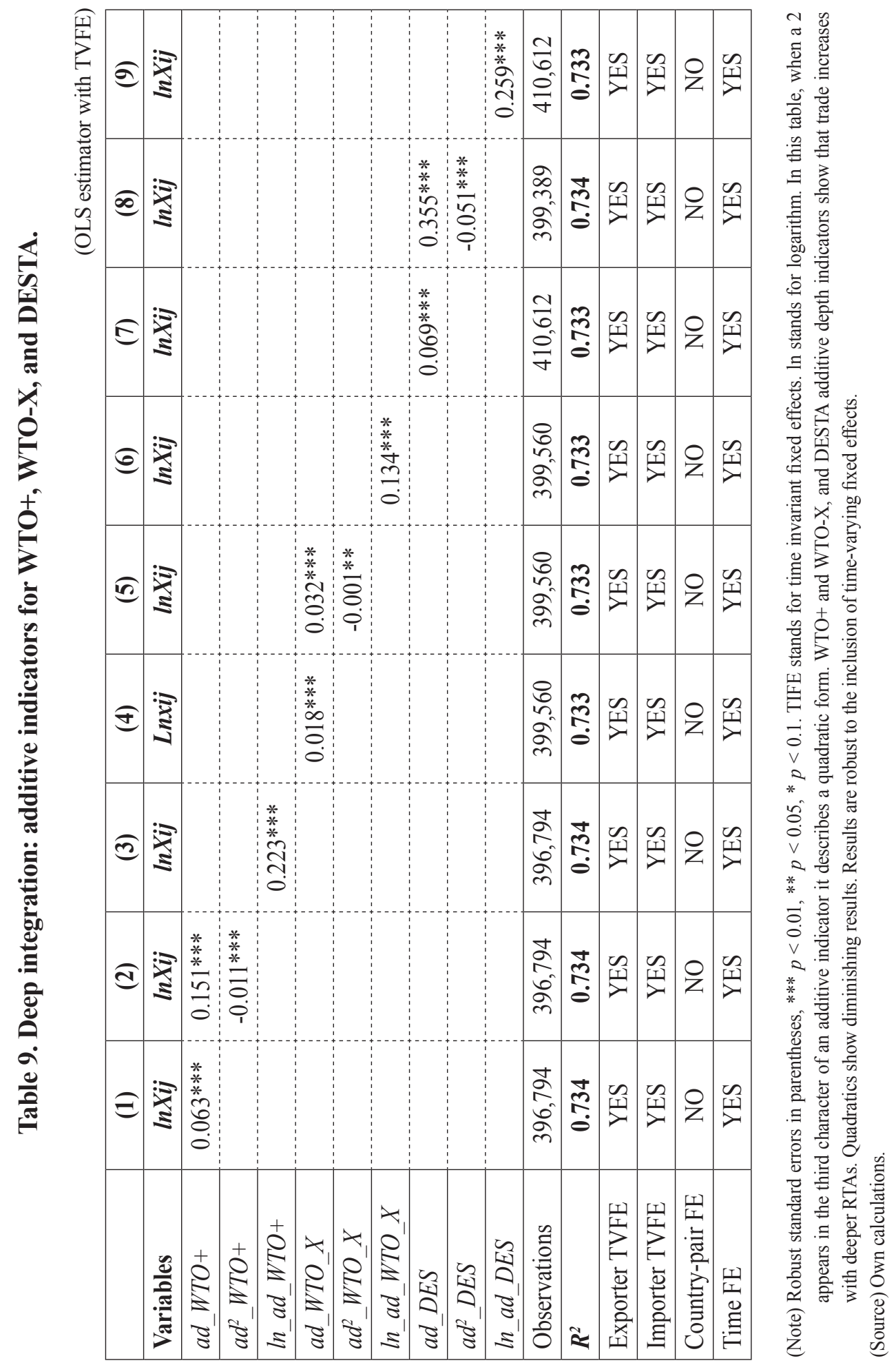


At first glance, the OLS-based estimates including time-varying country fixed effects do not appear to sustain the Table 4 results computed using PPML and timeinvariant fixed effects, where progression to RTA ranges with more provisions promotes trade in an increasing pattern. Yet, the introduction of time-varying fixed effects using the PPML method, as in column 3, suggests that the results' sensitivity stems from the estimation method but not the presence of time-varying country fixed effects. Therefore, we can claim that the results are robust to the introduction of time-varying fixed effects under the PPML method, which is acknowledged as being one of the methods better suited to the estimation of gravity equations.

With respect to the WTO-X provisions, using PPML with the inclusion of timevarying country fixed effects, as in column 6 of Table 10, produces estimates that are very close to the PPML time-invariant country fixed effects estimates in Table 3 . This confirms that deepening the integration of non-traditional WTO-X provisions has a greater impact on bilateral exports at an early stage in the integration process than it does at the final stage when diminishing returns seem to be at play.

The Baier and Bergstrand technique with OLS, time-varying fixed effects, and country-pair fixed effects in column 5 seems to amplify the effects found with PPML and time-varying country fixed effects on the four-year interval as presented in column 6 , but the main conclusion of positive, significant results still stands despite an apparent downturn in the advantages of WTO-X deepening of integration in the final stage.

As can be seen in column 7 and column 8 of Table 10, changing the estimation method to OLS with time-varying fixed effects produces sensitive variations. In contrast, column 9 bears out our Table 3 results and shows that the DESTA-based provision classifications are robust to the introduction of time-varying fixed effects while maintaining the PPML estimator for the four-range grouping of provisions. 


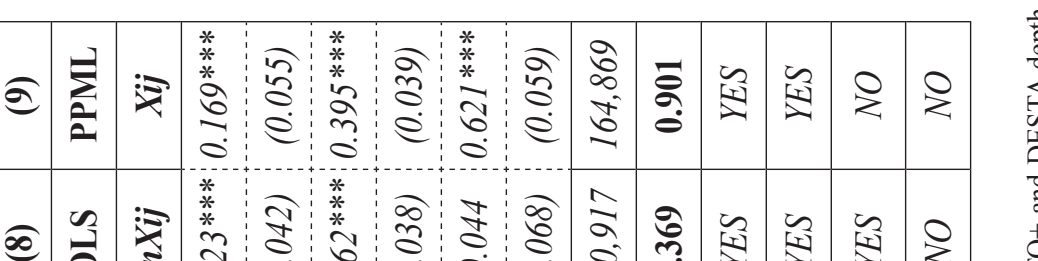
焉

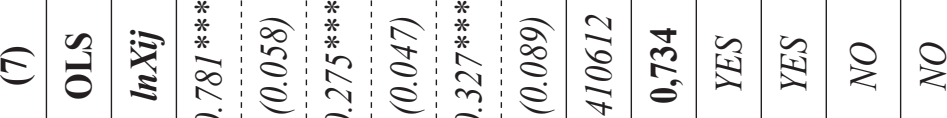
한

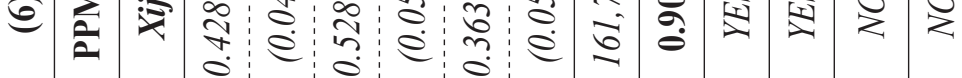

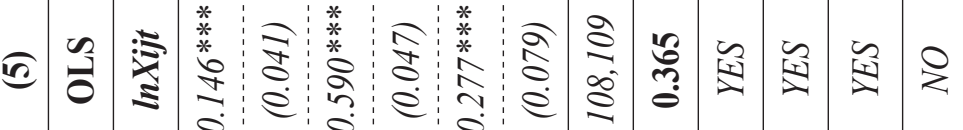

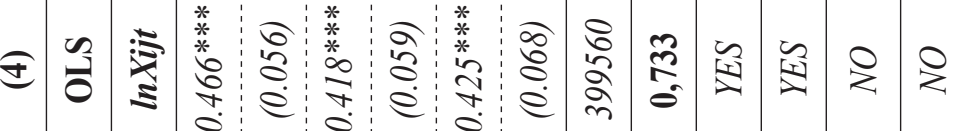

\begin{tabular}{|c|c|c|c|c|c|c|c|c|c|c|c|c|c|c|}
\hline & & & $\begin{array}{l}\nexists_{1} \\
\overbrace{}^{\prime} \\
\Xi^{\prime} \\
\Xi^{\prime}\end{array}$ & & 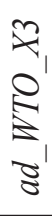 & & 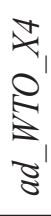 & & & & & & & \\
\hline (ூ) & $\sum_{\hat{A}}^{B}$ & : & $\begin{array}{l}* \\
* \\
* \\
* \\
\infty \\
0 \\
0\end{array}$ & $\begin{array}{l}2 \\
\stackrel{8}{0} \\
\stackrel{0}{2}\end{array}$ & 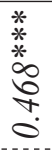 & $\begin{array}{l}\underset{Ð}{\delta} \\
\stackrel{d}{e}\end{array}$ & $\stackrel{*}{*} \underset{*}{*}$ & $\underset{\mathbb{Z}}{\stackrel{\mathbb{Z}}{e}}$ & $\begin{array}{l}2 \\
\bar{\sigma} \\
\bar{\sigma}\end{array}$ & $\stackrel{\hat{\sigma}}{\hat{\sigma}}$ & 过 & 预 & $\stackrel{\wp}{z}$ & $\gtrless$ \\
\hline (ㄴ & $\frac{n}{0}$ & 诘 & 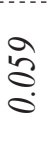 & $\begin{array}{l}\widehat{\widehat{\delta}} \\
\stackrel{0}{e} \\
\text {. }\end{array}$ & 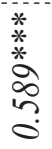 & $\stackrel{\overparen{2}}{\stackrel{2}{e}}$ & $\begin{array}{l}* \\
* \\
* \\
\infty \\
\stackrel{0}{0} \\
\stackrel{0}{0}\end{array}$ & $\begin{array}{l}\overparen{7} \\
\mathbb{8} \\
e\end{array}$ & $\begin{array}{l}\tilde{a} \\
\tilde{a} \\
\approx\end{array}$ & 旡 & 迳 & 贫 & 战 & $\gtrless$ \\
\hline 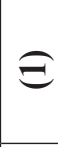 & $\frac{\pi}{0}$ & 标 & $\stackrel{\mathbb{2}}{\stackrel{0}{0}}$ & $\begin{array}{l}0 \\
0 \\
0 \\
0\end{array}$ & $\begin{array}{l}* \\
* \\
* \\
* \\
? \\
0\end{array}$ & $\begin{array}{l}\stackrel{8}{\circ} \\
\stackrel{0}{8}\end{array}$ & \begin{tabular}{l}
$*$ \\
$*$ \\
$*$ \\
\multirow{2}{*}{} \\
$\stackrel{0}{0}$ \\
0
\end{tabular} & 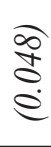 & $\begin{array}{l}\text { à } \\
\text { } \\
\text { ra }\end{array}$ & 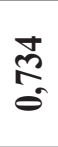 & 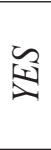 & 蒈 & $\gtreqless$ & $\gtrless$ \\
\hline & & $\frac{\frac{\pi}{0}}{\frac{\pi}{\pi}}$ & 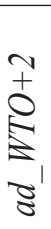 & & 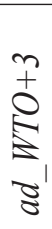 & & 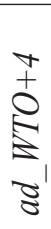 & & 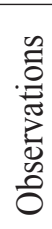 & ह & 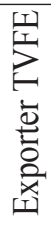 & 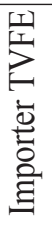 & 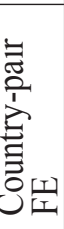 & 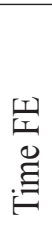 \\
\hline
\end{tabular}


As in the case of additive indicators in Table 10, distilled indicators of depth are robust to the introduction of country time-varying fixed effects under the OLS estimator. The same general conclusions pointing to a positive significant impact of agreement depth on bilateral exports remain valid. The specifications, in terms of level, find a slight upturn for the WTO+ and Rasch indicator, with the latter being more pronounced. The log specification of the WTO+ MCA remains virtually unchanged, while the log specification of the Rasch depth indicator presents an upturn. The WTO-X provisions show a slight downturn in terms of level. They also display a more pronounced decrease in the log specification. The quadratic specification also reacts to this sensitivity analysis without producing any change in the basic interpretation. (see Table 11.)

The Baier and Bergstrand technique facilitates the introduction of country-pair fixed effects together with time-varying country fixed effects. Here again, the Table 5 results for the distilled indicators remain robust as can be seen in Table 12. The Rasch indicators bounce slightly upward in their level and log specifications with little quadratic variation. The WTO+ and WTO-X MCA depth indicators show a slight downturn in level with a more pronounced variation in their log specifications.

The downward shift of the MCA depth indicators induced by the Bair and Bergstrand technique is more marked than that without the inclusion of country-pair fixed effects. The quadratic forms post a downturn without any change to their main implications of diminishing returns to the integration process. 


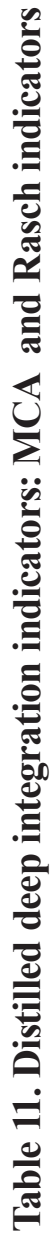

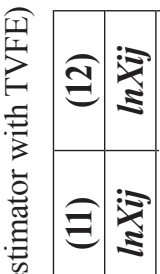

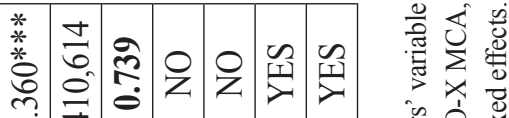
mo

ڤิ)

อิ

匊

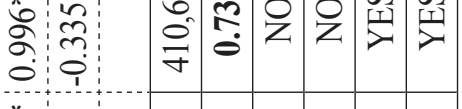

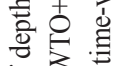

$\widehat{\sigma} \stackrel{:}{\Xi}$

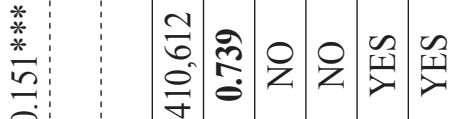

然吉

竞,

o

ब

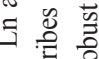

额

(⿻)

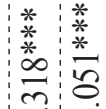

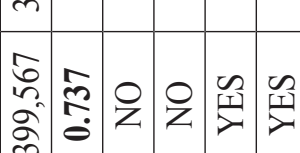

:

鹿.

so

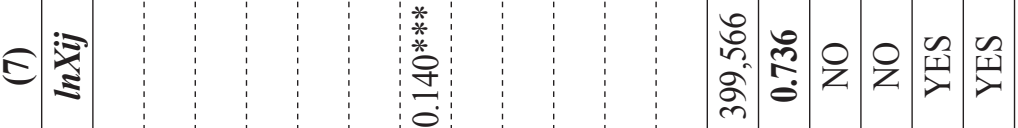

政

票

홍

案

$\theta \stackrel{=}{:}$

䔄

$\sqrt{(2)}$

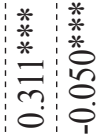

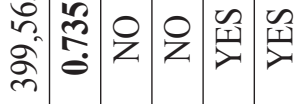

떠

$\geq 2$

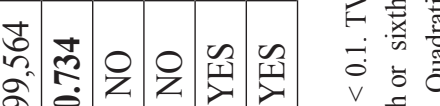

Q

*. อ

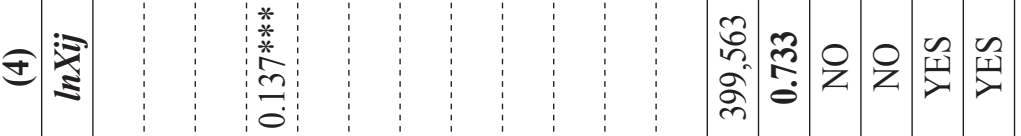

O.

8 年

*

* ह

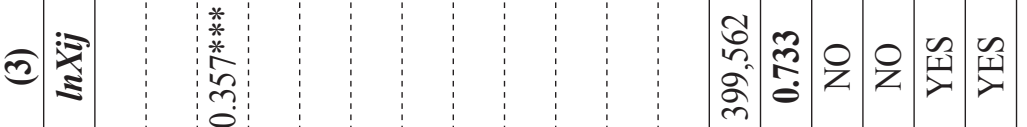

to

2 व

$* 3$

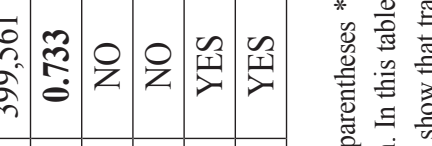

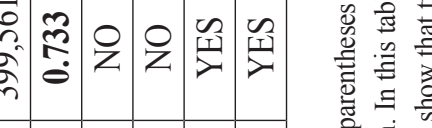

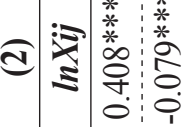

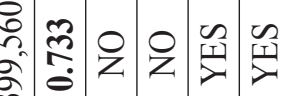

$\Xi$ 实

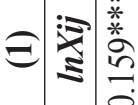

㺃

협 홍.

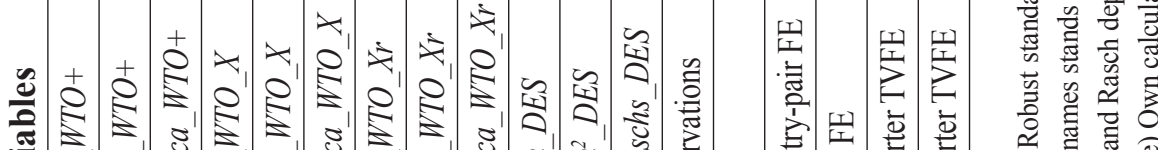

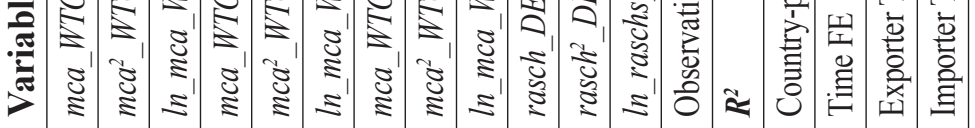

荦 도

है 


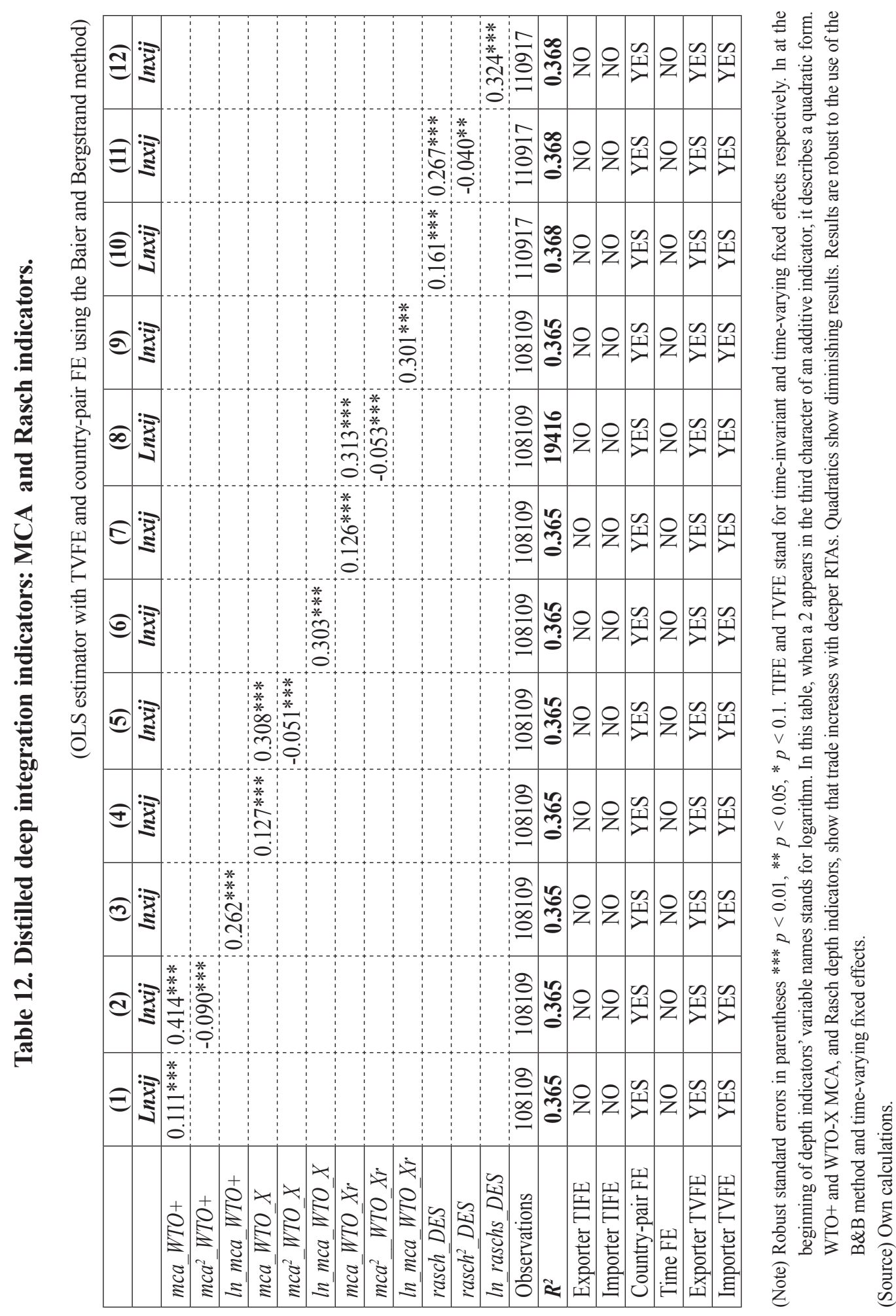




\section{Using PCA}

We perform a PCA on the WTO (2011) database to obtain an RTA depth indicator. This indicator is based on the first dimension predicted by the procedure, which is the one that captures most of the variability in the provision-based distribution of the RTAs. The first dimension of the PCA explains $39.9 \%$ of the variability in the data for the WTO+ provisions, $34.2 \%$ for WTO-X, and 35.7\% for WTO-Xr. We test the PCA depth indicator in our gravity model using specifications in level, quadratic, and logarithm forms. The first dimension of the PCA depth indicators is strongly correlated with the first dimension of the MCA depth indicators. One difference between the MCA and PCA results is that PCA produces substantially lower estimates for the WTO+ and WTO-X provisions. 
苞

\begin{tabular}{ll}
\multirow{2}{\infty}{$: \overrightarrow{2}$} \\
\hline
\end{tabular}

(2)

$E: \rightarrow$

$\bigcup_{0}^{\ll}$
$\ddot{0}$

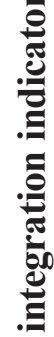

융

를

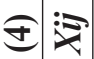

(2)

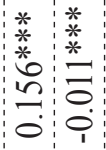

$\stackrel{*}{*}$

$*$

กิ

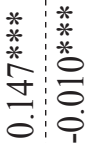

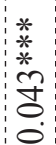

:

ช

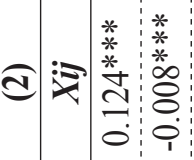

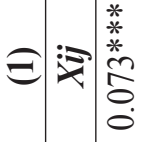

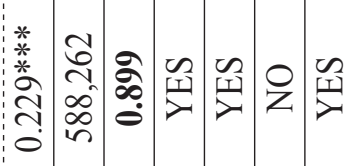

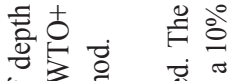

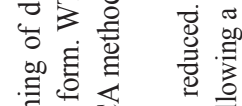

毛证 $>$

焉壳蓄

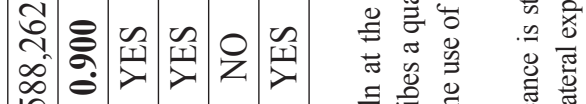

$\exists$ :

웡

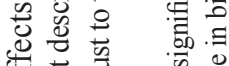

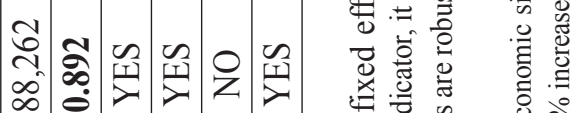

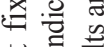

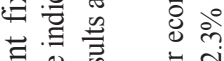

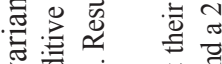

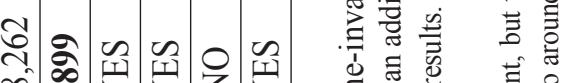

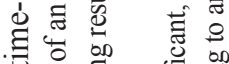

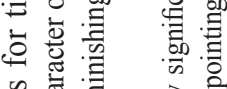

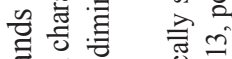

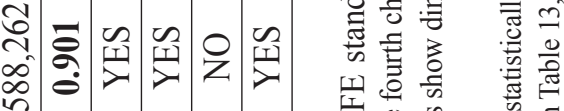

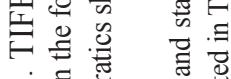

-

సै.

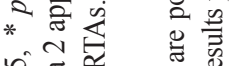

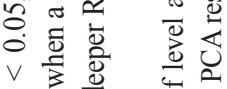

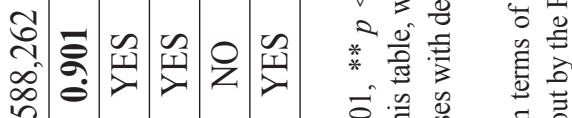

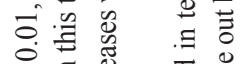

$\checkmark \leqq$ ठ

२ घं.

ஸิ

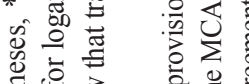

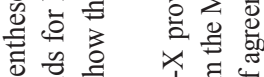

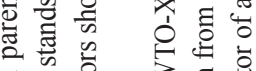

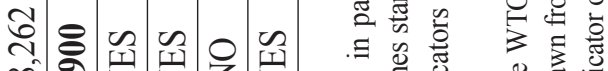

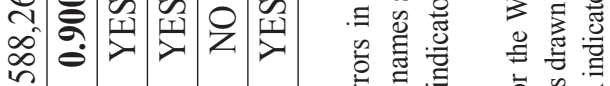

定专

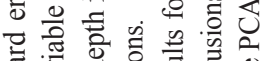

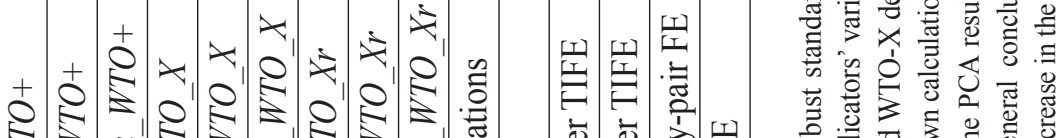

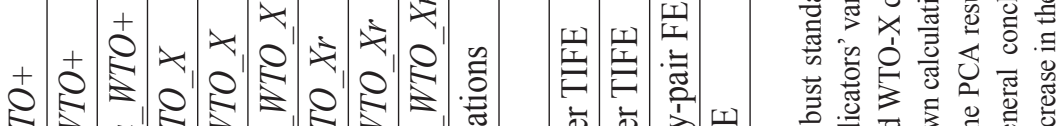

Ev

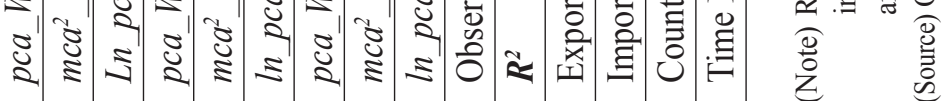




\section{Conclusions}

In the light of recent developments such as Brexit, increasing protectionism, and US President Donald Trump's confrontational approach to México and China, revised studies have become essential to guarantee that trade policy and decision making remain focused on the creation of a more prosperous world.

This study investigates the hypothesis that deeper RTAs do more to increase bilateral trade than shallow ones. After testing different indicators for agreement depth, we find no evidence to refute this hypothesis. Deep integration indicators are computed from two different datasets and tested in different specifications. They are plugged into the gravity equations in level, quadratic, and logarithmic form. Additive indicators are also tested as factor variables. Our research results for the different indicators of RTA depth confirm that deeper, rather than shallow RTAs promote trade. A 10\% increase in the depth of integration raises bilateral trade flows by some $3.0 \%$. This is a broad result derived from the increase in the number of provisions such as environmental, labor market and human rights clauses on RTAs.

Then, we can expect that an RTA with 22 clauses will produce some $3.0 \%$ more trade than a RTA with 20 provisions. Deeper RTAs contribute to the harmonization of institutions between trade partners that will benefit from sharing similar standards for technical barriers, public procurements or consumer protection, among many other issues. Nevertheless, the effect of the inclusion of any particular provision on trade creation is hard to isolate and check. The quadratic specification of the MCA and Rasch indicators suggests that the returns to further liberalization of trade decrease as integration increases, as expected. It is because marginal benefits can be diminished in the ongoing process of integration.

Our additive, MCA depth indicator results are robust to changes in the method of estimation to OLS, the Baier and Bergstrand technique, and the introduction of timevarying country fixed effects. Additive indicators, when treated as factor variables, are sensitive to computation methods whether we use the OLS method or time-varying fixed effects. Nevertheless, they are robust to the introduction of time-varying country fixed effects, maintaining PPML as the method of estimation. Sensitivity analysis of the additive depth indicators confirms the finding that deeper agreements increase trade more than shallow ones for WTO+ and DESTA classification of RTA provisions. A three-provision breakdown confirms this pattern for the WTO-X classification of RTAs, although a 
positive and decreasing impact of non-traditional WTO-X provisions of trade is found in the last stage of integration for the clusters of four and five ranges. Lastly, PCA depth indicators tested in the gravity model produce substantially lower estimates than those obtained with MCA but still reveal significantly positive effects of deeper agreements on bilateral exports.

One of the main limitations of deep integration studies stems from the difficulties in giving different weights upon each provision based on the importance of each one to trade. That is why we depend on additive, non-weighted indicators. Up to this point, an RTA with 20 provisions is defined to be deeper than one with 19, even though it is theoretically possible that the RTA with 19 provisions incorporates one highly tradeincreasing provision that is absent in the 20-provisions RTA. This in turn could imply that the 19 provisions-RTA would be deeper than the RTA with 20 provisions. MCA or PCA techniques mitigate the problem but do not give definitive answers as to which agreements are deeper. Although not entirely accurate, the depth indicators presented in this research provide enough clues to the direction of the impact of the heterogeneity of the agreements on trade.

Hence, if the intention of signing an RTA is to increase trade, we now know that a deeper agreement will work better, at least up to a certain limit. This study also contributes to clarifying the importance of other provisions related to trade and the traditional and the non-traditional WTO framework of negotiations regarding trade expansion. It shows that the introduction of more provisions is profitable in terms of trade creation.

Further studies are needed to improve our understanding by identifying provisions that are more effective to promote international trade, by addressing enforceability issues, and by quantifying the impact of deeper RTAs on economic growth and welfare.

Received 27 April 2017, Revised 12 June 2017, Accepted 17 July 2017 


\section{References}

Ahcar, J. and J. Siroën, "Deep Integration: Free trade Agreements Heterogeneity and its Impact on Bilateral Trade.” Université Paris-Dauphine IRD DIAL DT/2014-25 (2014), Paris.

Anderson, J. and E. van Wincoop, "Gravity with Gravitas: A Solution to the Border Puzzle." The American Economic Review 93 (2003): 170-192.

Anderson, J. "The Gravity Model.” Boston College - Department of Economics; National Bureau of Economic Research (NBER). Annual Review of Economics 3 (2011): 133-160.

Baier, S. and J. Bergstrand 'Do free trade agreements actually increase members' international trade?” Journal of International Economics 71 (2007): 72-95.

Baier, S., J. Bergstrand, and M. Feng, "Economic integration agreements and the margins of international trade." Journal of International Economics 93 (2014): 339350 .

Baldwin, R. and J. Harrigan, "Zeros, Quality, and Space: Trade Theory and Trade Evidence." American Economic Journal: Microeconomics, American Economic Association 3 (2011): 60-88.

Booysen, F., , S. Van Der Berg, R. Burger, M. Von Maltitz, and G. Du Rand, "Using an asset index to assess trends in poverty in seven Sub-Saharan African countries." World Development 36 (2008): 1113-1130.

Boughanmi, H., A. Al-Shammakhi, and A. Antimiani, “A Deeper Integration or Wider Integration?: the case of Gulf Cooperation Council". Journal of Economic Integration 31(2016): 206-233. DOI: https://doi.org/10.11130/jei.2016.31.2.206

Bourgeois, J., K. Dawar, and S. Evenett, "A Comparative Analysis of Selected Provisions in Free Trade Agreements." Study commissioned by DG Trade, Brussels: European Commission, Mimeo. 2007.

Cahuzac, E. and C. Bontemps, "Stata par la pratique : statistiques, graphiques et 
éléments de programmation.” Stata Journal (2008).

Dunteman, G. Series: Quantitative Applications in the Social Sciences. Sage Publications. 1989.

Dür, A., L. Baccini, and M. Elsig, "The Design of International Trade Agreements: Introducing a New Dataset." The Review of International Organizations 9 (2014): 353-375.

Fally, T. "Structural gravity and fixed effects." Journal of International Economics 97 (2015): 76-85.

Ghoneim, A., N. Péridy, J. Lopez and, M. Mendez, "Shallow vs. Deep Integration in the Southern Mediterranean: Scenarios for the region up to 2030." MEDPRO Technical Paper 13 (2012).

Harrison, A. and A. Rodríguez-Clare, "Trade, Foreign Investment, and Industrial Policy for Developing Countries." Elsevier. Handbook of Development Economics 5 (2010): 4039-4214.

Head, K. and T. Mayer, "Gravity Equations: Workhorse, Toolkit, and Cookbook." Chapter 3 in Gopinath, G, E. Helpman and K. Rogoff (eds). Elsevier. Handbook of International Economics 4 (2014): 131-195.

Hoekman, B., and D. E. Konan, "Deep Integration, Nondiscrimination and EuroMediterranean Free Trade. In Regionalism in Europe." ZEI Studies in European Economics and Law. Springer US 4 (2001): 171-194.

Horn, H., P. Mavroidis, and A. Sapir, "Beyond the WTO? an anatomy of EU and US preferential trade agreements." The World Economy 33 (2010): 1565-1588

Khor, M. (2008) Bilateral and Regional Free Trade Agreements Some Critical Elements and Development Implications. TWN editor. http://www.normangirvan.info/ wp-content/uploads/2010/01/khor-bilateral_and_regional_fta-mk-sept08.pdf. Accessed 9 February 2015.

Kohl, T., S. Brakman, and H. Garretsen, "Do Trade Agreements Stimulate 
International rade Differently? Evidence from 296 Trade Agreements." The World Economy, 39 (2016): 97-131

Kohl, T. "Do we really know that trade agreements increase trade?" Review of World Economics 150 (2014): 443-465.

Kleimann, D. "Beyond Market Access? : The Anatomy of ASEAN's Preferential Trade Agreements.” Journal of World Trade 48 (2014): 629-682.

Le Roux, B. and H. Rouanet, Multiple Correspondence Analysis. Series Quantitative Applications in Social Sciences. 163. Sage Publications. 2010.

Martínez-Zarzoso, I., F. Nowak-Lehmann and N. Horsewoodm "Are regional trading agreements beneficial? Static and dynamic panel gravity models." North American Journal of Economics and Finance 20 (2009): 46-65.

Martínez-Zarzoso, I. “The log of gravity revisited.” Applied Economics 45 (2013): $311-327$

Márquez-Ramos, L., I. Martínez-Zarzoso and C. Suárez-Burguet, Determinants of deep integration: examining socio-political factors. Open Economies Review 22 (2011): 479-500.

Official Journal of the European Union OJEU L 354 (2012). Trade Agreement between the European Union and its Member States and Colombia and Peru. http:// euroalert.net/en/ojeu.aspx?idd=25465. Accessed 5 December 2014.

Orefice, G. and N. Rocha, "Deep Integration and Production Networks: An Empirical Analysis.” The World Economy 37 (2013): 106136.

Péridy, N. and A. Ghoneim, "Middle East and North African Integration through the lens of Non-Tariff Measures.” Journal of Economic Integration 28 (2013): 580-609.

Rodrik, D., A. Subramanian and F. Trebbi, "Institutions Rule: the Primacy of Institutions over Geography and Integration in Economic development." Journal of Economic Growth 9 (2004): 131-165. 
Rose, A. "Do We Really Know That the WTO Increases Trade?" The American Economic Review 94 (2004): 98-114.

Santos Silva, J. and S. Tenreyro, "The log of gravity." The Review of Economics and Statistics 88 (2006): 641-58.

Santos Silva, J. and S. Tenreyro, "Further simulation evidence on the performance of the Poisson pseudo-maximum likelihood estimator.” Economics Letters 112 (2011): $220-222$.

Shadlen, K. "Exchanging development for market access? Deep Integration and Industrial Policy under Multilateral and Regional-bilateral Trade Agreements." Review of International Political Economy 12 (2005): 750-775.

Shahid, S "Does the nature of Regional Trade Agreements (RTAs) matter in Promoting Trade?” Geneve: Graduate Institute of International and Development Studies, Working Paper CTEI-2011-1 (2011): 1-45

Tinbergen, J. Shaping the World Economy: Suggestions for an International Economic Policy, New York : Twentieth Century Fund (1962).

Vicard, V. “Determinants of successful RTAs.” Economics Letters 111 (2011): 188-190. Vicard, V. "On Trade Creation and Regional Trade Agreements: Does Depth Matter?". Review of World Economics 145 (2009): 167-187.

World Bank WB (2017) Global Economic Prospects. A Fragile Recovery. June. World Trade Organization WTO (2011) World trade report 2011: the WTO and preferential trade agreements: from co-existence to coherence. Geneva. 


\section{Appendix 1: Variable sources and definitions for the gravity model}

\begin{tabular}{|c|}
\hline Sources \\
\hline $\begin{array}{l}\text { Bilateral Exports: International Monetary Fund (IMF), Direction of Trade Statistics Database } \\
\text { DWOTS (2013). }\end{array}$ \\
\hline $\begin{array}{l}\text { Current GDP and population: World Development Indicators (WDI) database, World Bank, } \\
\text { (2013). }\end{array}$ \\
\hline $\begin{array}{l}\text { Area, Island, and Landlocked, constructed by the author based on the World Factbook from } \\
\text { the Central Intelligence Agency of the United States of America (CIA) }\end{array}$ \\
\hline $\begin{array}{l}\text { Weighted distance, contiguity, col45 and comlang_eth9: CEPII (2013): Head, K., Mayer, T. } \\
\text { and Ries, J. (2010), Gravity dataset, obs. till } 2006 .\end{array}$ \\
\hline $\begin{array}{l}\text { Regional Trade Agreements: Constructed by the authors, based on the Regional Trade } \\
\text { Agreements Information System (RTA-IS), World Trade Organization WTO (2013) }\end{array}$ \\
\hline CEPII: Head, K., Mayer, T. and Ries, J. (2010), Gravity dataset. \\
\hline Rose, A. (2005) data set on The Multilateral (GATT/WTO) System and Trade obs. \\
\hline $\begin{array}{l}\text { GATT membership: Constructed by the authors based on World Trade Organization } \\
\text { information (2013). }\end{array}$ \\
\hline $\begin{array}{l}\text { OCDE membership: Constructed by the authors based on the Organisation for Economic Co- } \\
\text { operation and Development } \operatorname{OECD}(2013) \text { information. }\end{array}$ \\
\hline $\begin{array}{l}\text { Provisions analysis: WTO (2011) Research division for the World Trade Report and Design of } \\
\text { Trade Agreements DESTA-WTI (2014). }\end{array}$ \\
\hline $\begin{array}{l}\text { https://www.wto.org/english/res_e/booksp_e/.../wtrl1-anatomy_ptas_e.xls http://www. } \\
\text { designoftradeagreements.org/?page_id=884 }\end{array}$ \\
\hline Variable definitions \\
\hline $\boldsymbol{a d}$ WWT: additive index of provisions under the regular WTO framework \\
\hline$a d^{2} \_W T O: a d \_W T O$ squared \\
\hline In_ad_WTO: natural logarithm of (1+ad_WTO). \\
\hline ad_WTO_X: additive index of provisions outside the regular WTO framework. \\
\hline$a d^{2} \_W T O \_X: a d \_W T O \_X$ squared \\
\hline In_ad_WTO_X: natural logarithm of $\left(1+a d_{-} W T O_{-} X\right)$. \\
\hline $\begin{array}{l}\text { mca_WTO+: multiple component analysis index that captures the degree of depth of free } \\
\text { trade agreements based on the number and combination of traditional WTO+ provisions. }\end{array}$ \\
\hline 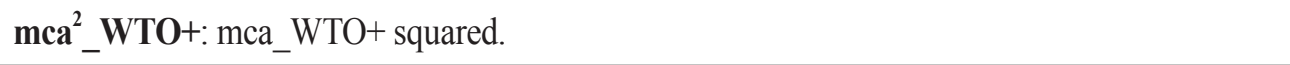 \\
\hline In_mca_WTO+: natural logarithm of $\left(1+m c a \_W T O+\right)$. \\
\hline
\end{tabular}


mca_WTO_X: multiple component analysis index from its first dimension of inertia that captures the degree of depth of free trade agreements based on the number and combination of provisions they present outside the traditional WTO framework.

$\boldsymbol{m c a}^{2}$ WTO_X: $m c a_{-} W T O \_X$ squared.

In_mca_WTO_X: natural logarithm of $\left(1+m c a \_W T O \_X\right)$.

mca_WTO_Xr: multiple component analysis index from its first dimension of inertia that captures the degree of depth of free trade agreements based on the number and combination of provisions they present outside the traditional WTO framework; it does not include agro, ipr and investment as they are commonly negotiated under the WTO framework.

$\boldsymbol{m c a ^ { 2 }} \boldsymbol{W} \boldsymbol{W} \boldsymbol{O}_{-} X \boldsymbol{X}$ : depth_mca_WTO_Xr squared.

In_mca_WTO_Xr: natural logarithm of $\left(1+m c a \_W T O \_X r\right)$.

$\boldsymbol{a d}$ DES: additive indicator based on DESTA classification of the provisions that are present in the agreements

$a d^{2} \_D E S:$ ad_DES squared.

In_ad_DES: natural logarithm of $\left(1+a d \_D E S\right)$

rasch_DES: index based on the Rash latent trade analysis from the DESTA team that captures the depth of the integration

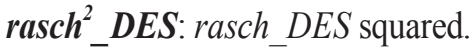

In_rasch_DES: natural logarithm of $(1+$ rasch_DES).

pca_WTO+: principal component analysis index that captures the degree of depth of free trade agreements based on the number and combination of traditional $W T O+$ provisions.

$\mathrm{pca}^{2}$ WTO+: $p c a \_W T O+$ squared.

Ln_pca_WTO+: natural logarithm of $\left(1+p c a \_W T O+\right)$

pca_WTO_X: principal component analysis index from its first dimension of inertia that captures the degree of depth of free trade agreements based on the number and combination of provisions they present outside the traditional WTO framework.

$p c a_{-}^{2}$ WTO_X: pca_WTO_X squared

In_pca_WTO_X: natural logarithm of $\left(1+p c a \_W T O \_X\right)$.

pca_WTO_Xr: principal component analysis index from its first dimension of inertia that captures the degree of depth of free trade agreements based on the number and combination of provisions they present outside the traditional WTO framework; it does not include agro, ipr, and investment as they are commonly negotiated under the WTO framework.

$p c a^{2}$ WTO_Xr:pca_WTO_Xr squared

In_pca_WTO_Xr: natural logarithm of $\left(1+p c a \_W T O \_X r\right)$. 


\section{Appendix 2: Countries in the sample}

\begin{tabular}{|c|c|c|c|}
\hline Albania & Djibouti & Korea, South & Russia \\
\hline Algeria & Dominican Republic & Kuwait & Rwanda \\
\hline Angola & Ecuador & Kyrgyzstan & Samoa \\
\hline Argentina & Egypt & Latvia & Saudi Arabia \\
\hline Australia & El Salvador & Lebanon & Senegal \\
\hline Austria & Equatorial Guinea & Liberia & Sierra Leone \\
\hline Azerbaijan & Estonia & Libya & Singapore \\
\hline Bahrain & Ethiopia & Lithuania & Slovakia \\
\hline Bangladesh & Fiji & Luxembourg & Slovenia \\
\hline Barbados & Finland & Madagascar & South Africa \\
\hline Belarus & France & Malawi & Spain \\
\hline Belgium & Gabon & Malaysia & Sri Lanka \\
\hline Belize & Gambia, The & Mali & Sweden \\
\hline Benin & Georgia & Malta & Switzerland \\
\hline Bermuda & Germany & Mauritania & Syria \\
\hline Bolivia & Ghana & Mauritius & Tajikistan \\
\hline Brazil & Greece & Mexico & Tanzania \\
\hline Brunei & Grenada & Moldova & Thailand \\
\hline Bulgaria & Guatemala & Mongolia & Togo \\
\hline Burkina Faso & Guinea & Morocco & Tonga \\
\hline Burundi & Guinea-Bissau & Mozambique & Trinidad and Tobago \\
\hline Cambodia & Guyana & Nepal & Tunisia \\
\hline Cameroon & Haiti & Netherlands & Turkey \\
\hline Canada & Honduras & New Zealand & Turkmenistan \\
\hline Cape Verde & Hong Kong & Nicaragua & Uganda \\
\hline Central African Republic & Hungary & Niger & Ukraine \\
\hline Chad & Iceland & Nigeria & United Arab Emirates \\
\hline Chile & India & Norway & United Kingdom \\
\hline China & Indonesia & Oman & United States \\
\hline Colombia & Iran & Pakistan & Uruguay \\
\hline Congo, Democratic & Iraq & Panama & Uzbekistan \\
\hline Congo, Republic of the & Ireland & Papua New Guinea & Venezuela \\
\hline Costa Rica & Israel & Paraguay & Vietnam \\
\hline Cote d'Ivoire & Italy & Peru & Yemen \\
\hline Croatia & Jamaica & Philippines & Zambia \\
\hline Cuba & Japan & Poland & Zimbabwe \\
\hline Cyprus & Jordan & Portugal & \\
\hline Czech Republic & Kazakhstan & Qatar & \\
\hline Denmark & Kenya & Romania & \\
\hline
\end{tabular}




\begin{tabular}{|c|c|c|c|c|c|c|c|c|c|c|c|c|c|c|c|c|}
\hline 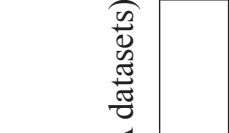 & 总离的言 & 尽 & $\begin{array}{l}\infty \\
0 \\
0\end{array}$ & 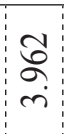 & & & & & & & & & & & & \\
\hline 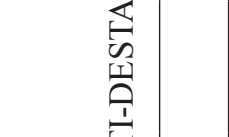 & 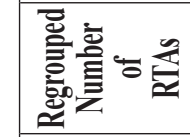 & $\approx$ & 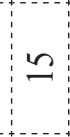 & $=$ & & & & & & & & & & & & \\
\hline 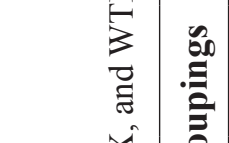 & 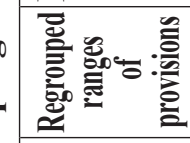 & $\frac{0}{1}$ & 오 & $\begin{array}{l}\hat{n} \\
\dot{\sim}\end{array}$ & & & & & & & & & & & & \\
\hline 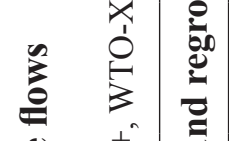 & 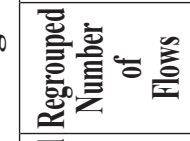 & $\begin{array}{l}\infty \\
\stackrel{\infty}{n} \\
m \\
=\end{array}$ & $\begin{array}{l}n \\
\tilde{n} \\
m\end{array}$ & $\begin{array}{l}0 \\
m \\
\cdots \\
0\end{array}$ & \begin{tabular}{l}
$\infty$ \\
\multirow{\sigma}{\sigma}{} \\
0
\end{tabular} & $\begin{array}{l}\infty \\
0 \\
\text { ñ }\end{array}$ & $\begin{array}{l}5 \\
\infty \\
\text { i }\end{array}$ & & & & & & & & & \\
\hline 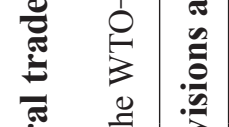 & 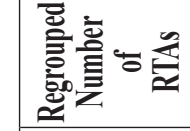 & $\underset{m}{\infty}$ & શે & $=$ & $\nabla$ & $n$ & 0 & & & & & & & & & \\
\hline 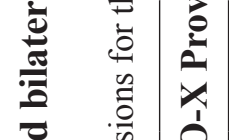 & 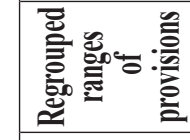 & $\stackrel{n}{\sim}$ & $\frac{0}{b}$ & $\begin{array}{l}n \\
=\end{array}$ & ণొ & $\frac{⿱}{1}$ & 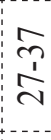 & & & & & & & & & \\
\hline 点 & 离的言 & $\begin{array}{l}\infty \\
\infty \\
n \\
n\end{array}$ & $\begin{array}{l}0 \\
\stackrel{1}{7} \\
+\end{array}$ & $\begin{array}{l}\widetilde{ح} \\
\text {. }\end{array}$ & $\stackrel{\infty}{=}$ & $\begin{array}{l}+ \\
⿱ \\
i\end{array}$ & $\stackrel{\mathcal{I}}{\sim}$ & $\frac{m}{n}$ & $\infty$ & $\begin{array}{l}\mathbb{D} \\
\infty\end{array}$ & 志 & $\stackrel{\infty}{n}$ & $\frac{n}{7}$ & న & $\begin{array}{l}n \\
6 \\
m\end{array}$ & $l_{-0}^{0}$ \\
\hline 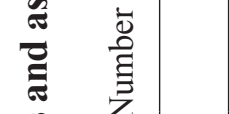 & 言配是 & $=$ & $\infty$ & ナ & - & $\infty$ & in & $\infty$ & $\infty$ & $\Xi$ & $\begin{array}{l}ナ \\
\end{array}$ & $\sim$ & $\checkmark$ & $\sim$ & N & - \\
\hline$\simeq$ & 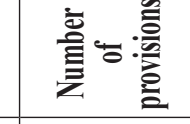 & - & $N$ & $m$ & $\nabla$ & $n$ & 6 & - & $\infty$ & $a$ & 으 & $=$ & $\simeq$ & $\stackrel{2}{=}$ & $\Xi$ & $n$ \\
\hline है & 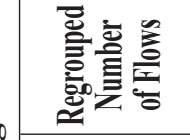 & $\begin{array}{l}\text { to } \\
\infty \\
0 \\
0\end{array}$ & $\begin{array}{l}J \\
2 \\
2\end{array}$ & $\begin{array}{l}\tilde{O} \\
0\end{array}$ & & & & & & & & & & & & \\
\hline 范 & 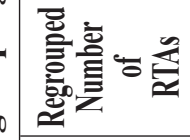 & \pm & $\bar{m}$ & i & & & & & & & & & & & & \\
\hline 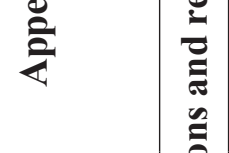 & 预 & I & 7 & $=$ & & & & & & & & & & & & \\
\hline 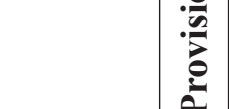 & 言亮亮 & 官 & 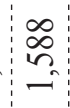 & $\frac{\infty}{ナ}$ & $\begin{array}{l}\text { ป } \\
\text { ָू }\end{array}$ & ชิ & 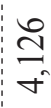 & $\frac{N}{6}$ & \begin{tabular}{l}
0 \\
0 \\
0 \\
\multirow{7}{*}{}
\end{tabular} & 吉 & \begin{tabular}{l}
$\Delta$ \\
$⿱$ \\
\hdashline
\end{tabular} & $\stackrel{\infty}{\sim}$ & & & & \\
\hline $\begin{array}{l} \pm \\
0 \\
2 \\
z\end{array}$ & 言竞氛 & $n$ & $m$ & 6 & $r$ & $r$ & $\infty$ & $a$ & I & $=$ & $\Xi$ & 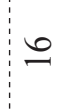 & & & & \\
\hline & 言的狺 & - & 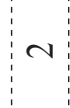 & $m$ & $\nabla$ & $n$ & 6 & - & $\infty$ & $a$ & 으 & $\Xi$ & & & & \\
\hline
\end{tabular}




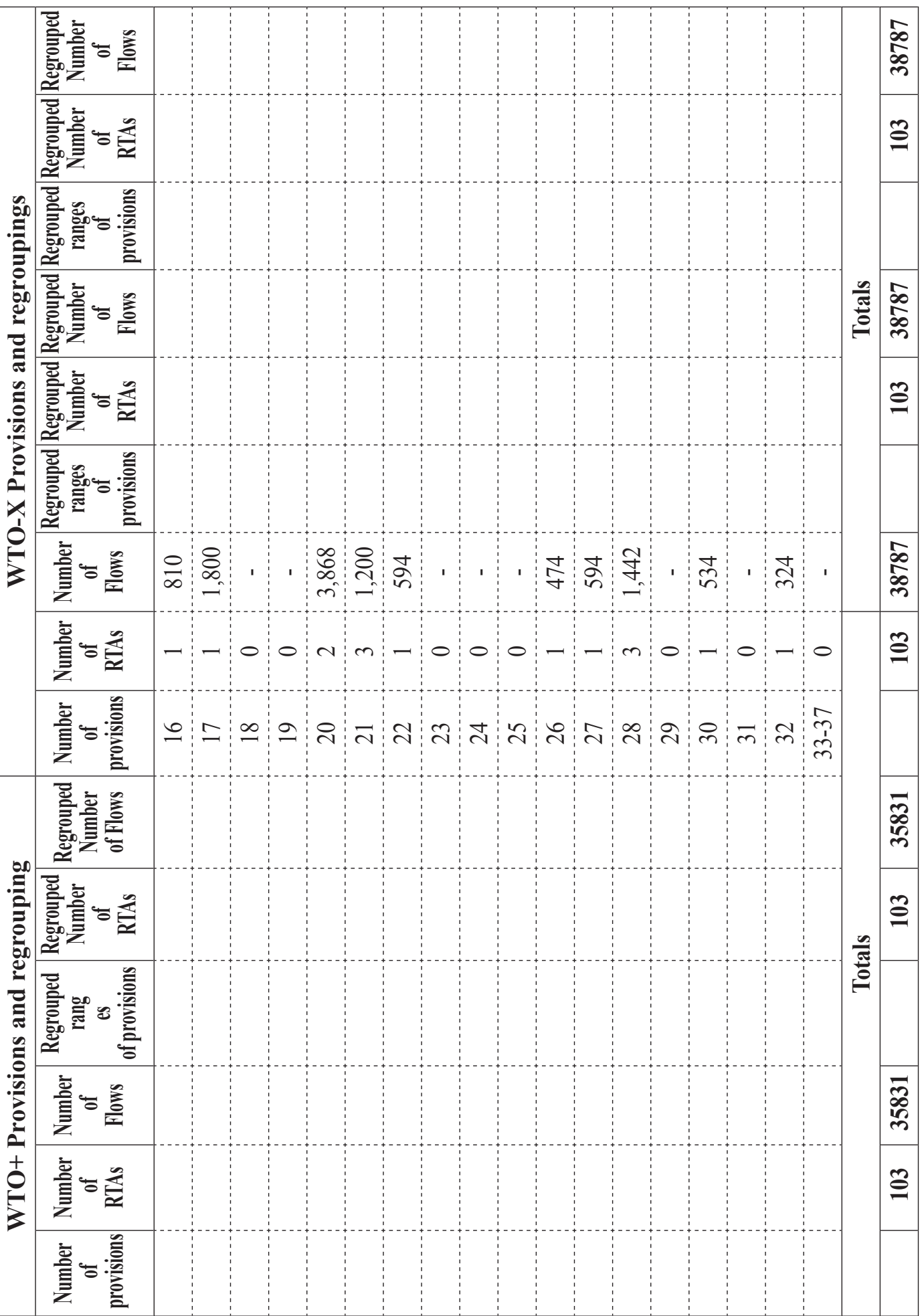




\begin{tabular}{|c|c|c|c|c|c|}
\hline \multicolumn{7}{|c|}{ WTI-DESTA Provisions and regrouping } \\
\hline $\begin{array}{c}\text { Number of } \\
\text { provisions }\end{array}$ & $\begin{array}{c}\text { Number of } \\
\text { RTAs }\end{array}$ & $\begin{array}{c}\text { Number } \\
\text { of Flows }\end{array}$ & $\begin{array}{c}\text { Regrouped } \\
\text { ranges of } \\
\text { provisions }\end{array}$ & $\begin{array}{c}\text { Regrouped } \\
\text { Number of } \\
\text { RTAs }\end{array}$ & $\begin{array}{c}\text { Regrouped } \\
\text { Number of } \\
\text { Flows }\end{array}$ \\
\hline 1 & 25 & 4,236 & $1-3$ & 136 & 20,827 \\
\hline 2 & 43 & 6,317 & $4-6$ & 93 & 26,601 \\
\hline 3 & 68 & 10,274 & $7-8$ & 40 & 3,186 \\
\hline 4 & 34 & 8,461 & & & \\
\hline 5 & 33 & 4,962 & & & \\
\hline 8 & 26 & 13,178 & & & \\
\hline 6 & 26 & 1,233 & & & \\
\hline & 14 & 1,953 & & & \\
\hline
\end{tabular}

(Source) Own calculations on data from WTO (2011) and WTI-DESTA (2014) 